\title{
O PENSAMENTO POLÍTICO DE HEGEL À LUZ DE SUA FILOSOFIA DO DIREITO ${ }^{1}$
}

\author{
Wellington Trotta
}

\begin{abstract}
RESUMO
O objetivo deste trabalho é analisar o pensamento político de Hegel a partir de sua "Filosofia do Direito", apresentando uma exposição sistemática daquilo que o autor compreendeu por filosofia, na qual a política é uma conseqüência inevitável, já que o seu sistema teórico privilegia a unidade lógica. Utilizei, na elaboração do presente texto, um critério muito simples: apresentar o pensamento político hegeliano à luz do seu próprio tempo, levando em consideração as dificuldades normais que todos sentem na expressão de idéias universais a partir de experiências singulares. Com isso, desejo assinalar que, embora Hegel tenha pensado o Estado dentro da perspectiva do universal concreto, seu olhar é prussiano e voltado aos problemas da unidade alemã. O artigo está dividido em duas partes. A primeira é uma exposição do conteúdo filosófico do autor, ao passo que a segunda parte procura fazer um estudo sistemático do seu pensamento político, tendo por limite sua “Filosofia do Direito". Essa sistematização é compreensível, já que, originalmente, o presente texto fazia parte de minha Dissertação de Mestrado, em que pude fazer uma relação entre Hegel e o pensamento de Marx em 1843, tal como expresso em "Crítica da Filosofia do Direito de Hegel”. Ao final, como conclusão, argumento que, mesmo sendo relevante o conjunto das críticas de Marx, o pensamento hegeliano parece retratar não só o Estado moderno, mas também o contemporâneo, sobretudo o dos últimos trinta anos, em que cada vez mais o poder Legislativo perde, por motivos diversos, o seu papel de legislar, sendo substituído pelo poder Executivo, ao qual cabe o incremento do universal no seio das particularidades.
\end{abstract}

PALAVRAS-CHAVE: Hegel; Filosofia do Direito; Marx; Estado moderno; filosofia alemã.

\section{INTRODUÇÃO}

No princípio do século XIX, ocorreram grandes transformações nos cenários artístico, filosófico e científico alemães, que, retomando agudamente a cultura grega, pode ser tipificada, nesse contexto, como uma espécie de "renascimento". É nesse ambiente que surge a obra de Georg Wilhem Friedrich Hegel (17701831), que, por sua originalidade filosófica, inaugurou uma nova forma de pensar a relação entre sociedade e Estado. Pode-se considerar que, com Hegel, tem início o período contemporâneo da história do pensamento filosófico e toda sua influência no pensamento político ocidental. Hegel é um marco definitivo. Pela sua ambição intelectual, por seus vastos conhecimentos e por seus esforços permanentes em elaborar uma síntese filosófica, passa à posteridade como uma referência fundamental na Filosofia Política.

${ }^{1}$ Como ex-bolsista, o autor agradece ao apoio da Fundação de Amparo à Pesquisa do Estado do Rio de Janeiro (Faperj).
Hegel nasceu em Stuttgart, no dia 27 de agosto de 1770 . Filho de um modesto funcionário público do Departamento de Finanças do Ducado de Würtemberg, recebeu uma educação não diferente dos jovens de sua época, destacando-se nos estudos de latim e história clássica. Por influência de seu pai e pelos seus méritos como bom aluno, obteve uma bolsa ducal para cursar Teologia na Universidade de Tübingen. Ao formar-se, em 1793, recebeu "um certificado que declarava ser ele um homem bem-dotado e de bom caráter, bem preparado em teologia, mas sem nenhuma aptidão em filosofia” (DURANT, 1996, p. 278), mais tarde desmentido pela história.

No Seminário, Hegel foi fortemente influenciado por Friedrich Wilhelm Joseph Schelling (1775-1854) e Johann Christian Friedrich Höelderlin (1770-1843). Este apresentara ao futuro autor da Filosofia do Direito os encantos da Grécia clássica, ao passo que Schelling abriu-lhe uma nova perspectiva filosófica na relação realideal. Afirma-se que Hegel, Shelling e Höelderlin, numa manhã, bem cedo na praça do mercado, plantaram uma “árvore da liberdade” em 
homenagem ao sucesso da Revolução Francesa de 1789. Isso retrata o impacto positivo do quanto a Revolução animava não só a camada culta alemã, como também sua própria juventude.

Os primeiros escritos de Hegel, chamados escritos da juventude ${ }^{2}$, têm como tema central a problemática teológica ${ }^{3}$, isso porque o futuro professor de Berlim formulou inúmeras reflexões acerca do cristianismo, sempre tendo a cultura grega como norte ideal de organização política. Em tais escritos primeiros, Hegel chega a comparar Jesus a Sócrates, uma vez que humaniza aquele na tentativa de estabelecer um paralelo, não só de personalidades, como também envolver os aspectos culturais que cada um representou ante suas respectivas culturas. Hegel via, no cristianismo, um avanço considerável - em relação ao indivíduo - face ao judaísmo, que, para ele, era uma religião positiva no sentido de que as normas eram emanadas diretamente de Deus numa prescrição de comportamento a partir de um código exterior aos homens. O cristianismo, ao contrário, constituía-se em um avanço, justamente por ser inverso ao judaísmo, pois seu caráter subjetivo proporcionava ao homem um sentido de liberdade individual, que ligava os homens dentro de uma comunidade humana. Para Hegel, o cristianismo desenvolve a subjetividade quando os homens, pelo amor uns para com os outros, criam um sentido de comunidade que faz lembrar a cidadania ateniense, isto é, o homem pela dimensão do cidadão.

Nesse período, destacam-se os seguintes escritos de Hegel: Fragmentos sobre religião popular e cristianismo (1793-94), Vida de Jesus (1795), A positividade da religião cristã (17951796) e $O$ espírito do cristianismo e seu destino (1798-99). Esses textos foram publicados depois da morte do autor em um único volume intitulado Escritos teológicos juvenis de Hegel. Embora nesse conjunto de escritos houvesse uma preocupação teológica, Hegel não só evita fazer uma apologia à

2 Hermann Glokner (1896-1987) é responsável por uma edição da obra de Hegel com o fito de aproximar a filosofia hegeliana dos irracionalistas contemporâneos, sendo formulador da tese que implica o jovem e o maduro Hegel. Ver Lukács (2007, p. 91).

3 Segundo Lukács, foi Wilhelm Dilthey (1833-1911) o formulador da tese de um "suposto" momento teológico no percurso filosófico de Hegel (ibidem). teologia como também se preocupa com a dimensão política da vida, já que o indivíduo situase como ser em sociedade (KONDER, 1991, p. 7). Pode-se dizer que Hegel toma sua cultura religiosa e tenta viabilizá-la a partir da perspectiva do que entende por cidadania ateniense, buscando compatibilizar os elementos do cristianismo com os da Filosofia grega. Essa será uma preocupação permanente em sua obra. Mais tarde, na Filosofia do Direito, retomando o tema, seu enfoque é o cidadão como voz do indivíduo, em que o Estado como unidade política é o centro da vida ética coletiva.

Por volta de 1800, Hegel transferiu-se para Iena a convite de Schelling, com o fim de lecionar na Universidade da cidade. Esse momento marcou, decisivamente, a vida de Hegel, pois à medida que começava a lecionar na referida instituição, dava prosseguimento aos seus estudos filosóficos propriamente ditos. Hegel, após a publicação da Fenomenologia do espírito, em 1807 - que trata dos movimentos necessários da consciência, do seu despertar até o que poderia chamar-se de tomada da essência da realidade -, aprofunda seu conhecimento filosófico e torna sua filosofia cada vez mais abstrata na busca de uma razão universal que não seja fruto de particularidades e opiniões, mas um esforço do espírito que se pensa a si mesmo no cenário histórico da consciência.

György Lukács (1885-1971), no livro O jovem Marx e outros escritos filosóficos, assinala que Hegel, ao contrário de muitos, inclusive do próprio Marx, que o criticava acusando o seu pensamento político de conservador por desconsiderar os problemas da realidade material dos indivíduos, cultivou leituras sobre economia, chegando a ler autores como Adam Smith (1723-1790), tomando, do economista escocês, o conceito de "trabalho", e aplicando-o ao longo da Fenomenologia do espírito (LUKÁCS, 2007, p. 92).

Seguindo a publicação da Fenomenologia do espírito, Hegel apresenta ao publico, em 1813, a Ciência da Lógica, que tem por fim um estudo ontológico, uma reflexão sobre o ser. Em 1817, apareceu a primeira versão da obra Enciclopédia das Ciências Filosóficas. Nesse livro Hegel procurou coroar seu sistema de forma a dividi-lo em três momentos, isto é, em três volumes, assim como na sua dialética tríade. O primeiro momento foi dedicado ao estudo da lógica por meio de uma grande síntese; no segundo momento, a sua 
Filosofia da Natureza; no terceiro e último, estuda a Filosofia do Espírito. Em Berlim, por volta de 1827, Hegel retoma a Enciclopédia e promove algumas modificações com o escopo de atender as premissas do seu sistema, sem com isso alterar o sentido originário que lhe dera na edição anterior, publicando o texto pela última vez em 1831.

No terceiro volume da Enciclopédia das Ciências Filosóficas, Hegel ensaia o que mais tarde aprofundará com a publicação de sua Filosofia do Direito, em 1821, ou seja, o estudo do Estado (eticidade): as relações entre universal-particular; como são possíveis suas possibilidades no plano político e em que medida o Direito efetivaria a liberdade ao mesmo tempo em que a normatividade, como dimensão pública, resguardaria os homens nas suas relações sociais necessárias.

Aos 61 anos de idade, Hegel morre em 13 de novembro de 1831, vítima de cólera, passando à posteridade como um dos poucos filósofos a alcançar, em vida, grande notoriedade pública, tanto no mundo acadêmico como no mundo político, deixando em toda a Alemanha uma herança intelectual sem precedentes na história do pensamento ocidental. De seus escritos serão construídas diversas escolas filosóficas importantes e de grande conseqüência política.

Depois desse breve histórico, cumpre-se destacar que o objetivo deste trabalho é analisar o pensamento político de Hegel a partir de sua Filosofia do Direito, apresentando uma exposição sistemática daquilo que o autor compreende por Filosofia, tomando a política como conseqüência inevitável, isso porque o seu sistema teórico privilegia a unidade lógica. Nesse sentido, optei por restringir-me à obra citada na intenção de buscar o substantivo conceitual de política em Hegel, sem com isso discutir outros textos da mesma natureza de sua autoria, anteriores ou posteriores à sua obra política por excelência. É preciso esclarecer, ainda, que o estudo direto do pensamento político de Hegel está circunscrito à análise do Estado, portanto, à terceira seção da terceira parte, "A moralidade subjetiva", especificamente dos parágrafos 261 a 313, embora faça incursões em outros parágrafos quando necessário.

Utilizei na elaboração do presente texto um critério muito simples: apresentar o pensamento político hegeliano à luz do seu próprio tempo, levando em consideração as dificuldades normais que todos sentem na expressão de idéias universais a partir de experiências singulares ou culturais. Com isso, desejo assinalar que, embora Hegel tenha pensado o Estado dentro da perspectiva do universal concreto, seu olhar é prussiano e voltado aos problemas da unidade alemã, logo suas reflexões por vezes são ideais e por outras realistas, dependendo de como Hegel entra e sai do problema, ou seja, o filósofo alemão procura, no interior do seu sistema, contemplar a relação particular-universal.

O artigo está dividido em duas partes. A primeira é uma exposição sumária do conteúdo filosófico do nosso autor, ao passo que a segunda, mais extensa, procura fazer um estudo sistemático do seu pensamento político, tendo por limite sua Filosofia do Direito. Essa sistematização é explicável, porque, originalmente, o presente texto fazia parte de minha Dissertação de Mestrado, em que pude fazer uma relação entre o velho filósofo de Berlim e o pensamento do Marx de 1843, ou seja, o da Crítica da Filosofia do Direito de Hegel. A conclusão ficou restrita a algumas considerações que tomei por empréstimo do próprio Marx, que, ao criticar Hegel, toma novo rumo políticoepistemológico ao romper com a perspectiva idealista. Entretanto, isso seria assunto para outro artigo.

\section{PRINCIPAIS ELEMENTOS DA FILOSOFIA HEGELIANA}

A lógica hegeliana, ao contrário de ser uma teoria do conhecimento, é em verdade uma ontologia, isso porque o Ser, compreendido pela dimensão do pensamento, identidade absoluta, busca a superação do objeto-sujeito, ser-pensar ${ }^{4}$. Assim, a categoria lógica assume a perspectiva sistemática de explicitação de se conhecer o concreto pelo conceito como identidade da identidade da diferença. O conceito é o idêntico que se diferencia a si mesmo no processo lógico da dialética como superação. Nessa relação, o sistema identifica-se na premissa de que o Ser é o pensamento pensando a si mesmo como idéia absoluta. Todos os entes são idéias que existem em razão da representação do Espírito Absoluto,

4 “Ser e pensar são para Hegel o mesmo, e, na verdade, no sentido de que tudo é recebido de volta ao pensamento e determinado a ser o que Hegel simplesmente designa o pensamento pensado" (HEIDEGGER, 1973, p. 404). 
no qual se identificam pensar e ser, conceito e realidade. O absoluto é, por fim, o conceito, e o conceito, a própria identidade (LEÃO, 1977, p. 254).

Na concepção de Hegel, a Filosofia define-se como o conhecimento necessário ao conteúdo da representação do absoluto ${ }^{5}$, por isso o absoluto confundir-se-ia com o objeto da própria Filosofia, contrariando um postulado fundamental da filosofia kantiana expressa na Crítica da razão pura, que consiste na impossibilidade de se conhecer o objeto em si mesmo, o que reduz o conhecimento da coisa pelo fenômeno, pela manifestação exterior do objeto. Ao contrário, para Hegel, a lógica teria o papel de compreender o objeto pelo conceito: as condições do conhecimento nem estão arbitrariamente no sujeito, muito menos no objeto, mas sim numa estrutura lógica, na idéia, no conceito, por isso "filosofia é um conhecimento conceituante" (HEGEL, 1995a, p. 39-59).

Ressalte-se a importante diferença entre a lógica dialética e a lógica formal: esta se baseia na lógica de Aristóteles, que tem por fundamento os princípios da identidade e o da não-contradição, ao passo que na lógica dialética a contradição não é apenas aceita como também inerente ao próprio movimento do pensamento. A intenção de Hegel é justamente provar que a razão necessariamente efetiva-se no mundo e não é apenas uma idéia abstrata $^{6}$. Nesse caso, sua concepção de "conceito" difere da tradição filosófica. O conceito que Hegel descreve e concebe está em movimento, logo é dialético, porque o seu motor é a contradição. Por isso, o absoluto é percebido no pensamento pela lógica, e não, como postulava Schelling, por meio da intuição e fundido no absoluto (HEGEL, 1999a, p. 29).

Segundo o entendimento de Carneiro Leão: "Ser e pensar não se opõem como realidade. Não

\footnotetext{
5 “Hegel determina como 'meta' da filosofia: 'a verdade'. Esta somente é atingida no movimento da plenitude [...] Verdade é para Hegel a evidência do saber que se sabe a si mesmo" (idem, p. 409).

6 “O botão desaparece no desabrochar da flor, e poderia dizer-se que a flor o refuta; do mesmo modo que o fruto faz com a flor parecer um falso ser-aí da planta, pondo-se como sua verdade em lugar da flor [...] Sua natureza fluida faz delas momentos da unidade orgânica, na qual, longe de se contradizerem, todos são igualmente necessários” (HEGEL, 1999a, p. 22).
}

se pode determinar o dado da experiência sensível como real, contrapondo-o ao pensamento como se o pensamento não fosse real. Abandonar o pressuposto absurdo de que o sensível é o ser e o pensamento é o nada constitui a primeira condição para se pensar logicamente qualquer coisa [...]. A essência da abstração não está em se prescindir da matéria sensível, mas na elevação do sensível à estrutura universal do conceito” (LEÃO, 1997, p. 258).

Pondera-se que o pensamento para Hegel seria a estrutura universal como condição necessária para o conhecimento do objeto. O pensamento não se configura como algo nadificado, ou melhor, ser e pensamento não se opõem como sentidos opostos em que este se constitui em abstração daquele. Muito pelo contrário, é no pensamento que o objeto encontra a sua dimensão universal, sendo, portanto, concreto, enquanto o sensível apenas revela sua exteriorização como percepção da realidade pensada, porém, particularizada. A filosofia hegeliana é, antes de tudo, um sistema fundado sobre o Espírito Absoluto (HARTMANN, 1983, p. 326), que, por sua vez, é a síntese da relação dos espíritos subjetivo e objetivo. Toda filosofia hegeliana é filosofia da identidade, uma vez que este fundamento expressa-se na arte, na religião, na história e, por fim, no mundo ético, no Direito como conceito de Estado: "Além do que, por residir a filosofia essencialmente no elemento da universalidade - que em si inclui o particular -, isso suscita nela, mais que em outras ciências, a aparência de que no fim e nos resultados últimos que se expressa a Coisa mesma, e inclusive sua essência consumada” (HEGEL, 1999a, p. 21).

Percebe-se, mediante leitura da passagem citada, que, para Hegel, o sentido da Filosofia está na perspectiva do universal, assim como também é ela a expressão do universal pelo fato de buscar a coisa mesma, o “em si”, por isso a noção de unidade domina, de certa forma, o seu pensamento, isto é, o universal em si representa a própria totalidade e, como tal, aquilo que é particular encontra-se como elemento dentro do sistema, necessariamente. Hegel considera o seu sistema como uma alternativa ao particularismo filosófico de seu tempo e pretende que o mesmo inaugure uma forma de pensar que leve em conta a cultura e sua subordinação ao plano ideal como fio condutor histórico. Nesse sentido, assevera Hegel que "colaborar para que a filosofia se aproxime da forma da ciência - da meta em que deixe de 
chamar-se amor ao saber para ser saber efetivo é isto o que me proponho" (idem, p. 23).

Assim, a filosofia hegeliana apresenta-se como aquela que tem por responsabilidade a construção de um sistema capaz de dar conta da totalidade, visando colocar a Filosofia como expressão da verdade, e não se contentar com o papel de mera espectadora, já que sua importância está determinada pela coisa mesma, o absoluto em si, pelo saber efetivo. Esse saber realiza-se não só para conhecer o centro como para ser o próprio centro: a visão do conjunto, a partir do e dentro do conjunto. Portanto, “a filosofia é um modo peculiar de pensar, uma maneira pela qual o pensar se torna conhecer e conhecer conceituante" (HEGEL, 1995a, p. 40); nesse caso, o seu conteúdo é o efetivo, e não o abstrato. Por isso, a Filosofia é objetiva, ao passo que “uma opinião é uma representação subjectiva, um pensamento qualquer, uma fantasia que eu posso ter dum modo e outros de outro modo; uma opinião é coisa minha, nunca é uma idéia universal que existia em si para si. Mas na filosofia não contém nenhuma opinião, porque não existem opiniões filosóficas [...]. A filosofia é a ciência objetiva da verdade, é a ciência da sua necessidade: é o conceito por conceitos, não é opinar nem deduzir uma opinião de outra” (HEGEL, 1974, p. 51).

Segundo Hegel, as opiniões não são considerações filosóficas, e nesse particular inspira-se no postulado platônico da distinção entre doxa e episteme, opinião e ciência. Desse modo, o trecho acima assinala a concepção hegeliana de Filosofia: a linguagem pela qual a verdade apresenta-se como um lógico conceituante, procedimento que se refere a uma nova e específica forma de pensar, que não opera de uma dedução à outra necessariamente, mas por contradição de uma relação à outra. A linguagem hegeliana estabelece-se por qualificar o que se pensa por meio de uma forma peculiar de desenhar conceitos, utilizando expressões consideradas por ele científicas, precisas no sentido de relacionar adequadamente pensamento e objeto pensado, ou seja, pela reflexão do "em si” como algo essencial. Daí vem seu rigor extremo na exposição de um sistema que busca a natureza do conceito posto pelo conceito. E o conceito posto pelo conceito é um resultado filológico-filosófico que, longe de ser uma armadilha de opiniões, significa a própria verdade por meio de exposições conceituantes. A filosofia não é um jogo de opiniões, mas pensamento conceituante por meio de uma linguagem especificamente precisa.

A maneira pela qual Hegel pensa é dialética e consiste na relação inseparável dos contraditórios com o fim de apreender uma etapa superior que possa daí estabelecer uma síntese. Por isso, a Filosofia em Hegel é um plano lógico: “A lógica tem, segundo a forma, três lados: a) o lado abstrato ou do entendimento; b) o dialético ou negativamente-racional; c) o especulativo ou positivamente racional" (HEGEL, 1995a, p. 159). Esses três lados afirmados por Hegel não são partes da Lógica, e sim momentos do todo lógicoreal, o que ele chama de todo conceito ou de todo verdadeiro geral. Dessa forma, a dialética de Hegel envolve, no primeiro momento, um ou diversos conceitos fixos - a tese. Pensados esses mesmos conceitos, ensejam contradições no seio de suas relações, implicando a fase verdadeiramente dialética ou razão dialética (negativa) que necessariamente nega a anterioridade como movimento de superação - a antítese: "O resultado dessa dialética é uma nova categoria, superior, que engloba as categorias anteriores e resolve as contradições nelas envolvidas” (INWOOD, 1997, p. 100). Essa fase é denominada de especulação, positiva (síntese) ou, como sugere Hegel, unidades dos opostos, isto é, a negação da negação anterior que retoma a afirmação negada na totalização de "supressão e conservação das duas posições anteriores" 7 .

O pensamento filosófico de Hegel é um sistema complexo de unidades no qual a mesma estrutura processa-se em áreas diferentes do conhecimento. Hegel, como um grande filósofo sistemático, aplica as mesmas categorias aos mais variados problemas. Sua dialética tríade domina sua forma de apresentar e superar os mesmos. Pensa sempre no sentido de que o pensamento deve percorrer caminhos cíclicos, ou seja, sempre se realizando em si mesmo, na saturação de um conceito que

\footnotetext{
7 "Nesta configuração, destacamos um primeiro ciclo no qual partimos de uma posição afirmativa ou identitária - o momento da tese - suscetível de gerar sua própria negação que, amadurecida, irá constituir uma segunda posição - o momento diferencial da antítese. A tensão entre tese e antítese vai provocar a emergência de uma terceira posição, ou seja, de um momento da síntese, que é, concomitantemente, negação e afirmação, supressão e conservação das duas posições anteriores” (SAMPAIO, 2000, p. 36).
} 
impõe a busca de um outro, necessariamente mais completo, não por decorrência, mas como superação das contradições. E tais contradições são superadas logicamente pelas sínteses promovidas na tensão dos opostos, gerando novas oposições.

Hegel traça um panorama filosófico que tem por fim ser o limite da própria filosofia, fim de uma jornada que encontra em si o fechamento do grande ciclo, fim da história da filosofia, sistema que pretende ser o último capaz de dar conta da realidade ${ }^{8}$. Assim, "essa ciência é a unidade da arte e da religião. Por conseguinte, a filosofia se determina de modo a ser um conhecimento da necessidade do conteúdo da representação absoluta” (HEGEL, 1995b, p. 351). Essa passagem é esclarecedora por tratar das formas absolutas, arte e religião, totalizando a unidade na representação do espírito absoluto que só pode ser definido pela Filosofia, que em si é a unidade do saber. A Filosofia é uma ciência pelo objeto e pelo procedimento específicos: o absoluto e a dialética no desdobramento do pensamento. Podese ponderar que, para Hegel, a Filosofia representa a verdade no mundo dos homens, por isso que no seu sistema as opiniões constituem um obstáculo ao conhecimento do absoluto. "A filosofia se determina de modo a ser um conhecimento da necessidade do conteúdo da representação absoluta", implicando que a Filosofia seria aquele saber que explicaria o absoluto na condição de revelar sua dimensão de forma racional e dentro das estruturas da lógica, que, pesquisando o Ser atrelado ao pensamento, não como oposição, anunciaria sua identidade necessitante.

Completando essa linha de raciocínio, em uma passagem, nos seus Cursos de Estética, que amplia consideravelmente o que concebe por Filosofia, Hegel, mais uma vez, relaciona-a com a representação da verdade: "Pois somente a filosofia em seu conjunto é o conhecimento do universo como uma necessidade orgânica em si mesma, que se desenvolve a partir de seu próprio conceito e, em sua própria necessidade de se relacionar

\footnotetext{
8 “Agora torna-se claro em que medida a história da filosofia é o mais íntimo movimento na marcha do espírito, quer dizer, da subjetividade absoluta em direção a si mesma. Ponto de partida, avanço, passagem, retorno desta marcha, tudo é determinado especulativo-dialeticamente" (HEIDEGGER, 1973, p. 406).
}

consigo mesma como um todo que retorna a si como um mundo da verdade" (HEGEL, 2001, p. 47).

Por isso, a filosofia não pode ser uma opinião, assim como também não pode ser um primeiro resultado da sensação. Hegel com isso pretende que o seu sistema anuncie uma visão que só pelo conjunto é possível conhecer o elemento. É como se o elemento em si não pudesse ter sua existência determinada, pois só é reconhecido na representação do todo como realidade primeira. Essa realidade primeira é, com certeza, o princípio norteador das difíceis elaborações hegelianas, que, por determinação do seu conceito, não pode buscar o exterior para manifestar o que ocorre no interior, mas o exterior é, ao seu turno, uma determinação do interior. Assim, como os conceitos do "belo" e da "arte" são pressupostos necessários do sistema da Filosofia, a família, a sociedade civil e o Estado também são, portanto, pensados pelo espírito como realidades em si.

Se a Filosofia é ciência do absoluto, linguagem do absoluto que se pensa e mostra-se exteriormente aos homens pela consciência, ela só pode ser realização do absoluto, por isso não se pode olvidar que na sua tarefa esclarecedora tenha por missão precípua apresentar o absoluto como determinação na história, encontrando no Estado sua relação de efetivação. Esse papel que a Filosofia desempenha, segundo o idealismo alemão ${ }^{9}$, é a de identidade cultural, portanto, nacional, não tendo nenhum paralelo na história da Filosofia moderna, a não ser que se recue ao mundo grego, em que, sem sombra de dúvida, ela tem um papel relevante, na medida em que se cria uma linguagem específica a partir de problemas políticos e, como atesta Jean-Pierre Vernant (1992), o vocabulário filosófico tem origem na

\footnotetext{
9 Os termos “idealista” e "idealismo" surgem pela primeira vez com o filósofo alemão Gottfried W. Leibniz (16461716), mas é com George Berkeley (1685-1753), filósofo inglês, que adquirem o sentido que nós conhecemos, ou seja, como uma corrente filosófica que reduz toda a existência ao plano do pensamento, isso quando consideramos o pensamento segundo René Descartes (1596-1650). Já o idealismo alemão é uma corrente filosófica que surge no final do século XVIII, sob forte influência da filosofia kantiana. Sua premissa básica consiste na nãoexistência de coisas reais independentes da consciência (eu). O que pensamos representa-se expressamente ao plano do real.
} 
temática política, na vida citadina dos homens.

O idealismo alemão surge, então, como uma corrente filosófica impregnada do espírito germânico: a introspecção, o retorno aos valores esquecidos como sentido de afirmação política, a disciplina viva no intuito do objetivo determinado, a superioridade do sistema cultural como um valor sobre o resto da Europa. O idealismo alemão, como assinala Nicolai Hartmann, é expressão criativa de um sistema filosófico em que os fundamentos são últimos e irrefutáveis, totalização que se efetiva como reflexão profunda pela razão interiorizada, caracterizando-se como um sentimento de otimismo juvenil (HARTMANN, 1983, p. 9). O idealismo alemão procura sintetizar o espírito germânico diante da história, e com isso objetiva promover, face à Revolução Francesa, uma perspectiva de auto-reconhecimento.

A filosofia hegeliana representa a apoteose germânica, missão que o povo alemão traz consigo a fim de efetivar a realização da maturidade da Europa que soube ser história e consciência de $\mathrm{si}^{10}$. A Alemanha tem um projeto, e esse projeto só pode ser de natureza universal, a materialização do espírito objetivo, a concretização do espírito como referência, como principio de identidade. Nesse sentido, nenhuma outra corrente filosófica foi tão eloqüente quanto a hegeliana, nenhum outro filósofo alemão representou tão bem esse espírito de se pretender universal a mente filosófica dentro de um mundo comandado pelos mais ingênuos sentimentos. A síntese absoluta da Filosofia, construída por Hegel, reproduz os interesses de uma síntese germânica que não somente busca sua unidade, mas também o comando da Europa cristã. Assim como os antigos germânicos uniamse em torno do chefe para a superação dos grandes confrontos bélicos, nos tempos idos (ANDERSON, 1980, p. 117), os alemães do século XIX, especialmente os nacionalistas como Hegel, elegem o Império prussiano como a liderança racional para comandar a unificação política alemã. A síntese de Hegel é a síntese do espírito na

10 "Na história da filosofia, veremos que, para outras regiões da Europa em que as ciências e a cultura do entendimento se fomentaram com zelo e êxito, a filosofia, com excepção do nome , desvaneceu até da memória e da noção e acabou por morrer que ela se conservou na nação alemã como uma característica peculiar. Recebemos da natureza a sublime vocação de ser os guardas deste fogo sagrado” (HEGEL, 1991, p. 12). história, no mundo, por isso precisa dos instrumentos do mundo para a sua realização enquanto determinação da vontade.

O princípio da liberdade como valor, segundo Hegel, é de natureza germânica e, como tal, significa que o povo alemão deve realizar tal idéia, cumprir o fim para o qual está determinado ou mesmo para o qual se determinou como uma imposição a partir da consciência de si, da autoconsciência enquanto determinação de sua unidade cultural. Talvez esteja aqui a chave para compreender o entusiasmo que a filosofia hegeliana exerceu sobre boa parte da inteligência alemã, sobretudo naqueles jovens, por realizar seu papel dentro da história, da luta política por uma Alemanha conforme os novos tempos. Desse modo, Hegel, na Introdução da Filosofia da História, monta um quadro dividindo a história universal em quatro momentos, começando pelo Oriente, pela Ásia, passando pelo mundo grecoromano e terminando a caminhada do espírito no mundo germânico: "A história universal vai do leste para oeste, pois a Europa é o fim da história universal, e a Ásia é o seu começo. [...] O oriente sabia - e até hoje sabe - apenas que um é livre; o mundo grego e o romano que alguns são livres; o mundo germânico sabe que todos são livres" (HEGEL, 1999b, p. 93).

Essa divisão tem por fim assinalar que o conceito de Estado foi uma longa maturação na qual o seu elemento formal é a monarquia em que a liberdade materializa-se: "Em conseqüência, a primeira forma de governo que tivemos na história universal foi o despotismo; depois vieram a democracia e a aristocracia, e, em terceiro lugar, a monarquia" (ibidem). Hegel evidencia a realização do Estado como reino da liberdade pela determinação político-administrativa enquanto monarquia, instância do universal pela qual a idéia concretiza-se por meio do espírito tomando consciência de si na história.

Nessa perspectiva político-filosófica, o mundo constituído pelo espírito germânico tem a tarefa de realizar o reino da razão quando efetiva a realização da vontade que, não sendo particular, mas universal, desdobra-se na realidade histórica, na concretização do mundo político. Esse mundo político é dominado pela vontade do conceito de Direito, que se expressa na figura do Estado como reino ético, reino da liberdade, não de um ou de poucos, mas de todos. O espírito germânico seria então a liberdade como uma dimensão espiritual; 
nesse caso, realidade que se concluiu no momento em que o espírito determinou-se comunitariamente. Hegel inverte as determinações do real porque a natureza do seu pensamento é lógicoidealista, isto é, o objeto é uma realização do conceito como lógico-ideal, logo o pensamento dá as condições de todo o conhecimento. Não é o sujeito e muito menos o objeto que se pronunciam na qualidade de se apreender o conhecimento. Este último realiza-se como categoria lógica, por isso é sempre um conceito, uma idéia ${ }^{11}$.

Esse conceito só pode ser compreendido como determinação pela leitura do idealismo, que, segundo Hegel, é a expressão histórica da Filosofia. Assim, "La proposición que lo finito es ideal, constituye el idealismo. El idealismo de la filosofía no consiste en nada más que en esto: no reconocer lo finito como un verdadero existente. Cada filosofia es esencialmente un idealismo, o por lo menos lo tiene como su principio, y el problema entonces consiste sólo [en reconocer] en qué medida ese principio se halla efectivamente realizado. La filosofía es [idealismo] tanto como la religión; porque tampoco la religión reconoce la finitud como un ser verdadero, como un último, un absoluto, o bien como un no-puesto, eterno" (HEGEL, 1968, p. 136).

O verdadeiro ser não é aquele que se apresenta aos sentidos, mas aquele que é compreendido no pensamento como determinação última, isto é, as coisas são representadas pelo conceito; em última instância, é o pensamento - como ato - que determina a existência da realidade. Isso não quer dizer que os objetos não existam ou não tenham realidade; essa realidade, por fim, primeiro afigurase no pensamento como a que possibilita o conhecimento. Este não é um atributo do objeto, mas sim do sujeito que pensa conceituando. É preciso assinalar que no idealismo o objeto existe na idéia, na consciência, isto é, "não há coisas reais, independentes da consciência” (HESSEN, 1987, p. 102). Assim, conclui-se que o objeto,

\footnotetext{
11 "Para o idealista lógico o objecto gesso não existe nem em nós nem fora de nós; não existe pura e simplesmente, necessita de ser concebido. Mas isto tem lugar devido ao nosso pensamento. Formando o conceito de gesso, o nosso pensamento concebe o objeto gesso. Para o idealista lógico o gesso não é, portanto, nem uma coisa real nem um conteúdo da consciência; é um conceito. O ser do gesso não é, segundo ele, nem um ser real nem um ser consciente, mas um ser lógico-ideal” (HESSEN, 1987, p. 105).
}

por exemplo, o Estado, que, como universal abstrato, existe na idéia, torna-se universal concreto por meio dos cidadãos em que suas vontades efetivam-se historicamente, e a universalidade é tomada como algo "em si" que se torna "para si” no plano das relações objetivas.

Ao contrário do empirismo, que toma o real pelas impressões das sensações, o idealismo compreende o real pela unidade do objeto pensado, o que quer dizer que o Ser é uma apreensão do pensamento. O idealismo alemão afigura-se, portanto, como uma solução ao problema posto pela lógica empirista, que insiste ser o real uma determinação dos sentidos, em que o que se conhece está relacionado pela relação sujeitoobjeto externamente. Nesse caso, a lógica hegeliana apresenta o objeto como uma determinação da idéia, necessariamente.

\section{FILOSOFIA DO DIREITO: O POLÍTICO NO SISTEMA HEGELIANO}

A Filosofia do Direito, de Hegel, mais do que um tratado jurídico-político é, teoricamente, um tratado ético-político, estando na mesma tradição de A república, de Platão, Política, de Aristóteles, O príncipe, de Maquiavel, Leviatã, de Thomas Hobbes (1588-1679), O segundo tratado sobre o governo civil, de John Locke (1632-1704) e $O$ contrato social, de Jean-Jacques Rousseau (17121778); enfim, constitui um clássico do pensamento político ocidental. Seja como for, independentemente do ponto de vista de cada perspectiva, a obra política de Hegel é um marco dentro do pensamento político moderno uma vez que elabora uma crítica ao Estado e ao próprio liberalismo enquanto fundamento teórico dos homens públicos nos negócios públicos, a partir da ascensão da burguesia como classe hegemônica no século XIX.

O tema central dessa obra, sem prejuízo para os demais enfoques, está relacionado à efetivação do plano da liberdade como dimensão do Direito, no sentido da eticidade, em que o Estado assume a instância universal de superação de todas as particularidades (HARTMANN, 1983, p. 598). Sendo assim, o Estado, na concepção de Hegel, tem em si a idéia de representar a totalidade político-social, de encerrar em si o mundo público e o mundo privado, a restauração da vida ética a partir da representação grega. Hegel pensa a comunidade no sentido politicamente estatal, ou seja, por meio da norma jurídica como instrumento 
político a resguardar a liberdade, atingindo sua realização num elo comum a todos. O Estado é para Hegel, ao mesmo tempo, tanto poder como função, por sinal uma função política cujo escopo é o trato da coisa pública enquanto devidamente pública, isso para a satisfação do indivíduo, socialmente. O pensamento de Hegel é herdeiro da Revolução Francesa de 1789 e, como tal, tem na lei, portanto na legalidade, o fundamento da nação enquanto sociedade organizada, cujo fim é a liberdade como valor máximo de integralidade humana.

Na Filosofia do Direito, Hegel pensa uma ordem de instituições políticas que deveriam funcionar na devida medida em que os interesses universais sejam garantidos dentro dos particulares, delegando aos órgãos públicos a tarefa de, em si, resolver o social por meio do político. Hegel, que para muitos é considerado o "grande aristotélico moderno", pensa o homem a partir de uma ordem necessária que o antecede, ou seja, sua possibilidade enquanto homem só é possível dentro do Estado, a pólis moderna, cuja finalidade consiste numa eticidade pelo Direito, pelo plano da normatividade ${ }^{12}$.

Segundo Norberto Bobbio (1908-2004), a posição de Hegel diante do Direito é ambígua, uma vez que ora é parte do sistema (o Direito abstrato, como pensam os juristas), ora é o Direito como sistema, seja no sentido estrito ou na condição de uma filosofia prática - ordens econômica, política e moral (BOBBIO, 1995, p. 57-58). Ainda, conforme o pensador italiano, a matéria jurídica não está constituída organicamente, encontra-se desmembrada e desarticulada; observa-se o Direito Privado separado do Direito Público no sentido constitucional. Entretanto, ousando discordar de Bobbio, entendo que essa tal desarticulação é proposital, porque Hegel não elabora um tratado jurídico à guisa de manual didático, mas sim um

12 "Na ordem natural a cidade tem precedência sobre a família e sobre cada um de nós individualmente, pois o todo deve necessariamente ter precedência sobre cada um de nós individualmente" (ARISTÓTELES, 1997, p. 15). Ao chamar Hegel de "aristotélico moderno", tomo por base os seguintes autores: Marcuse (1984, p. 51): “A filosofia de Hegel é em amplo sentido a reinterpretação da ontologia de Aristóteles, liberada esta das distorções do dogma metafísico”; Ramos (1993): “A crítica ao modelo aristotélico-hegeliano, exposta por Marx, retrata uma outra posição teórica em relação ao Estado”. tratado político submetido aos princípios do idealismo. Por outro lado, Bobbio acerta quando assinala que Hegel rompe com a construção sistêmica do Direito, legada pela escolástica do Direito Natural, e isso é bastante razoável, pois na Filosofia do Direito, Hegel procura novos fundamentos como pressupostos de condição realizável e condensa ética e política na perspectiva que alenta por muitos anos: o ideal do mundo grego como resgate da síntese do cidadão e do indivíduo na retomada histórica, a ingenuidade germânica não afetada pela abstrata propriedade romana.

Instigante e ao mesmo tempo polêmica, a posição do pensador húngaro István Mészáros, ao defender a tese de que o pensamento político hegeliano, em sua formulação, optou pelo capital, muito embora apresentasse, naquele momento, as contradições da sociedade civil burguesa. Para o discípulo de Lukács, Hegel elaborou sua concepção política em tempos extremamente complexos, levando em consideração o seu momento decisivo que foi a Revolução Francesa de 1789. Segundo Mészáros, “o que deve ser enfatizado aqui é a importância do simples fato de que uma filosofia concebida do ponto de vista do capital, em determinado estágio do desenvolvimento histórico, tenha reconhecido os antagonismos históricos objetivos” (MÉSZÁROS, 2002, p. 55). Isso quer dizer que Hegel tornou-se um pensador difícil de ser rotulado, pois ao mesmo passo que é temeroso tê-lo por conservador, outra dificuldade é apresentá-lo como genuíno pensador liberal, mesmo Mészáros associando a filosofia hegeliana à burguesia enquanto classe que se constituía controladora do Estado moderno. Todavia, o que importa, decisivamente, é pensar Hegel como grande teórico: sempre predisposto a acertos, equívocos e contradições, peculiaridades de quem simplesmente pensa.

\section{III.1. Família, sociedade civil e Estado}

A Filosofia do Direito, de Hegel, pode ser tomada como uma tentativa de firmar o princípio racional como real, na medida em que a sociedade civil é apenas uma etapa que o espírito objetivo cumpre até se realizar como Estado: a verdade que se volta a si mesma, preocupada em ir ao encontro da história e dela resgatar a dimensão do homem. No seu entendimento, tanto a família quanto a sociedade civil são dois momentos que antecedem o Estado, mas que, na verdade, traduzem a idéia de Estado. Etapas as quais o 
Estado superou, como autodesenvolvimento de si na objetivação do plano da liberdade. Família e sociedade civil são reinos particulares diante do Estado; todavia, consideradas em si, constituem o desenvolvimento da idéia de liberdade, a passagem do contingente para o racional, isto é, o necessário. Família e sociedade civil são, segundo Hegel, necessidades em que o espírito no processo toma consciência de si.

No primeiro momento, a família, substancialidade imediata do espírito, determina-se pela sensibilidade (amor),e é a instituição em que o espírito adquire sua relação com o mundo externo, apresentando-se por meio de uma unidade. A família, de certa maneira, surge como relação racional, espírito ético imediato, sentido de superação da natureza, ou melhor, qualidade de promover o conteúdo para além do sujeito e da pessoa, a substancialização de membro, de um dentro de outros numa relação com todos (HEGEL, 1990, p. 160).

Na superação da família, que se caracteriza como reino das unidades particulares, Hegel apresenta a sociedade civil como uma disposição de encontrar uma associação mais ampla para resguardar, ainda assim, os mesmos interesses particulares, muito embora historicamente a consciência avance para complexas relações de si. Nesse sentido, a sociedade civil é a negação lógico-dialética da família, que, ao seu turno, será negada pelo Estado como reino ético, logo a sociedade civil é o momento em que os membros da família libertam-se da condição de membros de uma unidade para encontrarem em si o "aparecimento de pessoas independentes e reconhecidas como tais pela sua maioridade" (WEBER, 1993, p. 112), possível pelo reconhecimento do outro em si.

A sociedade civil, uma descoberta "como campo de atuação da reflexão filosófica” (FREITAG, 2002, p. 63), assume em si mesma um instante necessariamente fadado à sua superação, isso, porque, superando o reino das particularidades da família, não consegue ir além de uma superação tímida, que por sua vez acirra essas mesmas particularidades agora em bases não naturais, mas artificiais, nas classes e outras corporações. Eis que o Estado, a universalidade concreta, é absolutamente o fim das particularidades tomadas como centro, cedendo aos interesses gerais.
Família, sociedade civil e Estado são diferenciações que se negam uma a outra na condição de que a vida ética só existe no interior do Estado, o que significa dizer que o Estado não é compreendido somente como um aparelho político, mas como o novo sentido de pólis, unidade urbana em que os indivíduos são livres, mas atrelados sob a objetivação da lei. Por isso, para Hegel, a lei é o Direito objetivado, isto é, Direito positivo, sendo, portanto, aceito universalmente e também universalmente conhecido, tendo a lei a função de subordinar as partes da sociedade ao todo. A sociedade civil ainda, comparada ao conteúdo do Estado, segundo Hegel, assemelhase a um "todo contra todos" hobbesiano, pelo fato de não realizar o espírito da história que é a materialização da liberdade como valor máximo. A sociedade civil burguesa, mesmo suplantando o reino restrito da unidade familiar, ainda guarda o efeito de sua particularidade, porque ainda não foi realizada a passagem do abstrato ao real, e o formal ainda não foi superado pelo conteúdo determinado pelo sentido histórico do Direito.

\section{III.2. Constituição, Estado e seus poderes}

Após o advento da Revolução Americana, de 1776, da declaração da Constituição dos Estados Unidos da América do Norte, em 1787, e da eclosão da Revolução Francesa, de 1789, com suas sucessivas fases na qual se destaca sua radical constituição de 1793, o pensamento jurídicopolítico ocidental amadureceu a idéia de organização política, tendo por base uma constituição formal que estabelecesse os princípios reguladores de uma determinada formação social. A constituição como algo necessário à sociedade organizada é um fenômeno que data da Grécia antiga, especificamente da Atenas do período clássico, pois, para os gregos, o sentido de constituição estava relacionado à organização do governo, ou melhor, a sua forma de governo em vista da administração da cidade.

Na modernidade, a constituição assume também um caráter formal como determinação jurídica de limitação do poder real; as constituições surgem com o objetivo de se estabelecer leis em que todos se obriguem ao cumprimento do firmado mediante uma legislação exterior, isto é, de leis do rei para leis do reino. A Constituição deixa de representar forma de governo para firmar-se como um conjunto de princípios a constituir um Estado, dentro dos limites de sua ação, assumindo, por 
fim, o sentido de um grande contrato social, em que a soberania passa a ser exercida pelo poder estatal, sem implicações pessoais. Todavia, essa explicação não é suficiente para dar conta do imenso problema que a produção de bens atingiu depois da Revolução Industrial e da consolidação da burguesia como nova classe que reorganiza os Estados nacionais e consolida o capitalismo como modo de produção de bens. A legislação desponta, por meio das constituições orgânicas e dos códigos, como novo instrumento para resguardar novos e velhos interesses, firmando e definindo o conceito de propriedade privada para proteger a circulação de riquezas.

Com a Revolução Francesa, o corolário de que a nação tem na lei o seu fundamento, ganha proporção não só de necessidade jurídica como político-econômica, visto que desse debate está construindo-se aquilo que hoje se costuma chamar Estado de Direito, tendo a norma jurídica dimensão de autoridade suficiente para sobreporse aos governantes em favor de uma ordem pública voltada aos interesses coletivos.

As novas relações de produção, a expansão da indústria e do comércio e as garantias essenciais à realização dos negócios burgueses aceleram o sentido da lei como algo imprescindível no mundo moderno. Dentro desta modernidade, ao lado da construção do capitalismo, surge, relacionada a tudo isso, a Constituição como elemento fundamental de personalização política do Estado. A partir do conceito de Constituição como lei máxima do Estado, submetendo à sua autoridade, surge a tese de que a lei é uma determinação de ordem jurídico-político-administativa, ora comandada pelo espírito burguês. A Constituição não é, portanto, um puro princípio da razão jurídica, mas o resultado de interesses políticoeconômicos.

No entendimento de Hegel, a Constituição marca um momento de pura racionalidade jurídicopolítica, o momento em que a liberdade está posta pela garantia da determinação da idéia até chegar ao concreto de si, ou seja, pelos instrumentos efetivos da normatividade; por isso afirma que "por Constituição deve-se entender a determinação dos direitos, isto é, das liberdades em geral, e a organização de sua efetivação; e que a liberdade política só pode, em todo caso, formar uma parte dela” (HEGEL, 1995b, p. 311). Segundo Hegel, a Constituição determinaria a racionalidade do
Estado, o momento em que são superadas as particularidades da sociedade civil, organizandose num organismo vivo e necessariamente lógicoracional em que o Estado, na perspectiva de totalidade, é o universal concreto, centro de uma vida ética tendo o público e o privado como dimensões continuadas pela liberdade de todos: "A constituição política é, em primeiro lugar, a organização do Estado e o processo da sua vida orgânica em relação consigo mesmo. Neste processo distingue o Estado os seus elementos no interior de si mesmo e desenvolve-os em existência fixa” (HEGEL, 1990, p. 250).

No pensamento de Hegel, a Constituição é a materialização racional do Estado, o momento em que o próprio Estado, em si, torna-se efetivamente universal concreto dentro de uma dada organização social. A Constituição assume o sentido de determinação do Estado moderno pela plena configuração de sua legítima existência no limite das relações entre os homens: "a Constituição é racional quando o Estado determina e em si mesmo distribui a sua actividade em conformidade com o conceito, isto é, de tal modo que cada um dos poderes seja em si mesmo a totalidade” (idem, p. 251). Tinha Hegel entendido que a Constituição seria um elemento essencial do Estado moderno, o que o diferenciaria dos outros momentos desse conceito ao longo da história, e por isso, no seu sistema, a Constituição marca o Estado como organismo funcionando biologicamente, sendo as partes naturais subordinadas ao todo em si, enquanto os seus supostos poderes são apenas funções específicas.

Tanto assim, que Hegel não admite a clássica separação entre os poderes interpretada, segundo alguns, por Montesquieu (1689-1755), pois entende que tal concepção não só dificultaria a unidade do Estado como o fragmentaria. Esse organismo hegeliano é uma determinação lógica representada pela concretização da idéia, e, nesse caso, a concepção de poder de Estado difere substancialmente da dos seus contemporâneos, que pensam de alguma forma na construção de um Estado racional e efetivamente comprometido com a nova realidade burguesa: o plano da liberdade atomizante dentro de uma ordem política. Hegel, na percepção dessa nova realidade, parte do conceito de unidade do Estado e, para tanto, não confere à clássica separação dos poderes a importância que tem dentro do pensamento liberal contra o pensamento absolutista. 
Conforme Hegel, o Estado não poderia constituir-se em diversos outros poderes que não fossem o próprio Estado, um poder em si mesmo, visto que qualquer unidade em si e para si além do conceito de Estado levaria sua unidade de soberano a diluir-se e não efetivar o seu próprio conceito que é a concretização da liberdade. Os poderes não constituíam nenhuma determinação fora daquilo que o próprio espírito do Estado atingiu na história. A divisão dos poderes significaria a cisão do Estado como elemento histórico, não possibilitando que todos os indivíduos fossem livres. O Estado moderno é a maturidade histórica sob a qual os homens organizam-se e superam as particularidades, a fim de nele buscar o universal. Logo, o Estado só existe na medida de sua unidade, de sua universalidade. Pensá-lo dividido em poderes é pensá-lo dominado pelas esferas das particularidades, diluído privadamente.

Para Hegel, a concepção da separação dos poderes tem em si algo que, devidamente entendida, é importante no sentido da determinação da liberdade pública, mas que, para isso, é preciso, sobretudo, compreender que tal separação não pode passar de um princípio de distribuição de funções, não comprometendo a unidade soberana do Estado. Embora admirador de Montesquieu, a quem confere importância capital quanto à pesquisa das constituições, Hegel entende divisão de poderes como desconcentração de funções estatais: "Entre as concepções correntes, deverse-á mencionar a da necessária separação dos poderes. Poderia ser ela uma concepção muito importante, pelo que representa de garantia da liberdade pública, se fosse tomada no seu verdadeiro sentido [...]. É nela que se encontra o elemento da determinação racional. O princípio da separação contém, com efeito, como elemento essencial, a diferenciação, a razão na realidade" (idem, p. 252).

Na relação que Hegel estabelece entre realidade e pensamento, isto é, a realidade como produto daquilo pensado, a separação dos poderes afetaria de imediato a lógica do conceito, pois nisso consiste todo princípio de universalidade. A separação dos poderes, que pensa obstruir desconfianças e arbítrios, na verdade cumpre o papel de particularização do Estado, visto que sua soberania repousa numa unidade realizada no Estado como concreto histórico. A separação entre os poderes acirra as relações entre os mesmos, e cada um deles, na medida do possível, procurará mostrarse tão independente que, de alguma forma, redundará na dissolução do Estado como unidade orgânica. Embora guarde racionalidade, a concepção da independência dos poderes em si mesma não garante a harmonia dentro do Estado como também não garante a liberdade como algo necessário e vital para o indivíduo. Sendo assim, para Hegel, os poderes são, na verdade, diferenças substanciais, funções exercidas na lógica do todo precedendo às partes.

\section{III.3. Poderes estatais}

A maneira como Hegel constrói a relação entre as diversas funções de poder de Estado passa, forçosamente, pela sua lógica política na defesa da monarquia constitucional, tendo, no monarca, o instituto da soberania como a própria personificação do Estado, a unidade políticocultural da Alemanha, tendo à frente a liderança prussiana. A argumentação hegeliana tem o sentido de validar sua construção lógica, ou seja, ao rejeitar a tese da independência entre os poderes, Hegel rejeita a ilogicidade de como ela é apresentada, visto que o seu pensamento político em si sustentase na sua lógica como um corolário da razão: "Divide-se o Estado político nas seguintes diferenças substanciais: a - Capacidade para definir e estabelecer o universal - poder legislativo; b Integração no geral dos domínios particulares e dos casos individuais - poder de governo; c - A subjectividade como decisão suprema da vontade - poder do príncipe. Neste se reúnem os poderes separados numa unidade individual que é a cúpula e o começo do todo que constitui a monarquia constitucional" (idem, p. 253).

A pretensão de Hegel funda-se na perspectiva de que o Estado consiga manter-se na sua unicidade, tanto assim que pensa a monarquia como elemento político consistente desse projeto. Hegel insiste no ponto de que a tese da separação dos poderes como se apresenta pela discussão de seus defensores, que pensam saber o que dizem pelo entusiasmo, não difere, em si, das outras representações que estabelecem no Estado uma verdadeira disputa entre os poderes, quando na verdade o que se deseja é que uma função seja exercida em plena relação de conjunto, uma com a outra, ou melhor, que todas as atividades de poder tenham como princípio o conceito de Estado em cada momento que atue como tal. Cada função exercida deve representar a idéia de Estado e não 
a fração de Estado.

Segundo Thadeu Weber, "a interdependência dos poderes é apresentada como condição de possibilidade da organicidade do Estado. O conceito inclui em si a unidade da diversidade e a racionalidade da Constituição se dá, na medida em que essa integração se realizar” (WEBER, 1993, p. 151). Essa organicidade é a própria unidade do Estado que se apresenta como necessária relação entre as suas diversas atividades, que em si só pode ser reconhecido em sua totalidade e não pelas suas partes isoladas em si. O Estado, sendo o todo, logo, anterior às partes, tem sua integração relacionada à funcionalidade das partes como unidades ligadas pelo princípio da soberania. Nesse sentido, “o poder do príncipe contém em si os três elementos da totalidade, a universalidade da Constituição e das leis, a deliberação como relação do particular ao universal, e o momento da decisão suprema como determinação de si de onde tudo o mais se deduz e onde reside o começo da realidade. Esta determinação absoluta de si constitui o princípio característico do poder do príncipe que nós vamos desenvolver em primeiro lugar" (HEGEL, 1990, p. 258).

O poder soberano, chamado "poder do príncipe”, na verdade, constitui a própria soberania enquanto fundamento do Estado político. Nesse poder, Hegel procurou, por meio do monarca, centralizar toda a unidade do Estado, identificando na monarquia prussiana o motor da história alemã capaz de levar adiante o seu processo de unificação político-cultural. O poder soberano seria a síntese do poder público estatal, nele estando contidas as determinações necessárias à unidade de um Estado que tem na vida ética a tarefa de executar o plano da liberdade como autodesenvolvimento do conceito de Direito. O poder soberano, enquanto sentido da universalidade do Estado, dá-se em um sujeito específico, a pessoa do monarca, encarnando a soberania estatal por meio de sua unidade física como representação da unidade política estatal, além de decidir, efetivamente, o controle das diretrizes estatais.

No parágrafo 277, da Filosofia do Direito, há uma passagem significativa que demonstra uma preocupação quanto ao caráter universal do Estado, mesmo que depois Hegel contradiga-se com sua tortuosa adequação do real ao racional como ideal. Vejamos: "As diferentes funções e actividades do Estado pertencem-lhe como momentos essenciais e são inerentes às universais e objectivas e embora se liguem, à personalidade particular como tal de um modo exterior e contingente. As funções e os poderes do Estado, não podem, pois, constituir uma propriedade privada" (idem, p. 259).

A contradição consiste no fato de que, mesmo não constituindo uma propriedade privada, o Estado e suas respectivas funções são tratados por Hegel como se assim o fossem, isso na medida em que destaca um sujeito específico, uma personalidade individual como representação da soberania estatal. Hegel delega ao monarca a representação da unidade do povo alemão, a condição de chefe eleito para fins de natureza orgânico-social. Nesse particular, Hegel faz lembrar a organização dos antigos germânicos que em momentos difíceis elegiam um líder para que este guiasse os guerreiros no intuito de guardar a paz, resolver contendas entre as tribos e combater os inimigos nas guerras externas (cf. ANDERSON, 1980; GIORDANI, 1985): “Na decisão pode distinguir-se: a decisão, o cumprimento e a aplicação das decisões do príncipe e, de um modo geral, a aplicação e conservação do que já foi decidido, das leis existentes, das administrações e institutos que têm em vista fins coletivos. Esta função de absorção no geral é o domínio do governo e nele se compreendem também os poderes jurídicos e administrativos que imediatamente se referem ao elemento particular da sociedade civil e afirmam o interesse geral na própria interioridade dos fins particulares" (HEGEL, 1990, p. 272).

Observa-se de imediato a diferença de como Hegel separa as funções de Estado em franca oposição à clássica separação dos poderes dentro da tradição exposta por Montesquieu. O poder Governativo é aquele que leva a contento as decisões tomadas pelo poder soberano na pessoa do monarca e aquelas existentes no interior das leis. O poder Governativo seria, portanto, o braço administrativo do poder soberano, subordinado à idéia de soberania existente nas determinações legais e ideais do Estado, organizado a partir de uma necessidade que está intimamente ligada à concretização do conceito de Direito. Assim, os poderes Administrativo e Judiciário não são poderes em si mesmos, constituídos como independentes e subordinados ao princípio norteador que rege internamente cada vontade particular. Para Hegel, tanto a execução dos 
serviços administrativos como os judiciários estão centralizados no interesse do universal e, dessa forma, vinculados diretamente à soberania como expressão máxima do Estado. A execução da justiça prende-se, politicamente, ao fato de que toda decisão, mesmo que tenha caráter particular, deva, em princípio, estar em consonância com o espírito universal, que, sem dúvida, justifica o fim do Estado, a natureza deste e a sua existência como instância ideal na realização do Direito.

Aos olhos do pensamento político contemporâneo, qualquer subordinação de um poder a outro seria vista como um forte atentado ao Estado de Direito, uma violenta ruptura com os princípios firmados pela democracia representativa, sobretudo no que concerne à justiça, que tem no poder Judiciário uma espécie de corolário do liberalismo, uma salvaguarda dos direitos individuais. Importa ressaltar que Hegel atrela a administração da justiça ao poder governativo, por considerar tal serviço um ato da administração pública e não um serviço particular destinado ao particular. A administração da justiça tem para Hegel um caráter público de máxima relevância, e por isso está vinculada ao poder governativo sob orientação direta da universalidade do soberano, pois o seu conteúdo repousa na soberania do Estado. Nesse sentido, a administração da justiça assume, no pensamento hegeliano, dimensão estatal primordial, e não, como afirmam muitos, um aspecto conservador do seu pensamento político.

Pode-se afirmar que o poder governativo assume a processualidade da administração pública, cujos serviços públicos não são distintos em si e para si. O serviço público pensado na Filosofia do Direito tem a especificidade única de garantir o universal para todos aqueles que vivem no Estado. Serviço público tem natureza pública e, sendo assim, não pode sofrer solução de descontinuidade, deve estar atrelado ao íntimo interesse do Estado na prestação de superação das particularidades e arbitrariedades. A atomização do poder levaria à extinção daquele Estado politicamente constituído para realizar o plano do Direito, a efetivação da liberdade. Portanto, Hegel destaca: “Assim como a sociedade civil é o campo de batalha dos interesses individuais de todos contra todos, assim aqui se trava o conflito entre este interesse geral e os interesses da comunidade particular e, por outro lado, entre as duas de interesses reunidas e o ponto de vista mais elevado do Estado e de suas determinações” (idem, p. 273).

O interesse do Estado é sempre de fundo universal, com isso o poder governativo não pode operar de outra maneira senão como expressão soberana do Estado, e tal soberania visa, em si, à consecução de fins últimos na superação das diferenças particulares. O poder governativo não pode ser instituído e firmado a partir de princípios próprios, seus fundamentos só podem e devem ser os mesmos fincados no e pelo poder soberano, ao que o poder legislativo, segundo Hegel, é constituído pelas: "Leis enquanto tais, na medida em que elas carecem de determinações complementares e pelos assuntos interiores que são, graças ao seu conteúdo, completamente gerais. Este poder faz parte da Constituição que ele mesmo supõe e que, por conseguinte, está fora das determinações que provêm de si mesmo, embora o seu ulterior desenvolvimento dependa do aperfeiçoamento das leis e do carácter progressivo da organização governamental geral” (idem, p. 278).

No sistema político hegeliano, o poder Legislativo não se determina em si como um poder soberano, a partir daquilo que se convencionou chamar de "autonomia dos poderes", pois o aquele poder tem como figura a totalidade da sociedade civil. Nele imperam as relações de subjetividade, e por isso dele só podem emanar decisões que, mesmo gerais, não constituem em si a universalidade, o que só pode dar-se na soberania do Estado, pela representação do soberano, do monarca. Sua eficácia enquanto momento do conceito de Estado atrela-se ao poder governativo, porque é esse que tem por fim a consecução do serviço público por meio da burocracia, da classe estatal composta por indivíduos extraídos da classe média. Os três momentos do Estado, pensados por Hegel, estão intrinsecamente submetidos à idéia do Direito, ao concreto plano de uma ordem ideal de se efetivar o Estado como totalidade da vida moderna.

\section{A BUROCRACIA: FUNÇÃO DE ESTADO}

Na Filosofia do Direito, Hegel não trata a burocracia dentro de um capítulo à parte ou mesmo em longos parágrafos. Desenvolve o problema no correr das exposições dos parágrafos concernentes aos poderes governativo e legislativo, na tentativa de legitimar a superioridade dos servidores do Estado sobre qualquer outro serviço promovido fora do universal concreto, e apontar 
que o único titular do universal é o Estado na figura de seus agentes submetidos ao espírito do monarca. Destaque-se que o caráter da burocracia, para o filósofo alemão, assenta-se na racionalidade do Estado e está diretamente ligado ao espírito da Revolução Francesa e às estruturas de funcionamento do Estado prussiano, que, ao longo do século XVII e em diante, desde a reforma de Frederico Guilherme I por meio da Resolução de 1653, instituiu profundas mudanças na Prússia por meio de uma forte centralização administrativa, levada adiante por seus sucessores (ANDERSON, 1984, p. 280); por conseguinte, longe daqueles ideais contidos no espírito revolucionário de $1789^{13}$.

Por fim, o espírito da burocracia confunde-se com o espírito do Estado, porque, para Hegel, “no funcionamento do governo, dá-se uma divisão de trabalho. Deve a organização das autoridades satisfazer a exigência, difícil embora formal, de, em baixo, a vida social, que é concreta, ser governada de um modo concreto [...]. De uma natureza objectiva para si são os actos de governo; pertencem ao que já está decidido de acordo com a sua substância e devem ser executados e realizados por indivíduos” (HEGEL, 1990, p. 240, 274).

A existência da burocracia está determinada pela natureza do Estado, isto é, o Estado como tal e pensado por Hegel é a superação da sociedade civil naquilo que para o filósofo significa o reino das individualidades, de todos contra todos, isso para usar uma expressão hobbesiana que Hegel toma como um axioma em defesa de um Estado que compreenda seu papel de abarcar os indivíduos para si. Nesse sentido, a burocracia assume materialmente a existência do Estado como realidade determinada por um conjunto de funções e atribuições regulares em que só o poder público por meio do seu pessoal pode exercer. É pela burocracia que o Estado torna-se uma realidade concreta anunciando aos seus membros a disponibilidade dos serviços públicos de forma plena, constituindo, assim, "a vida social, que é concreta, ser governada de um modo concreto". De um modo objetivo, a burocracia para Hegel é a

\footnotetext{
13 Item V da Declaração de 1793: “Todos os cidadãos são igualmente admissíveis aos empregos públicos. Os povos livres não conhecem outros motivos nas suas eleições a não ser as virtudes e os talentos” (PINHEIRO, 1983, p. 149).
}

materialização da soberania que se processa por meio de indivíduos públicos.

O Estado, nas suas atribuições, não pode contar com a boa vontade das pessoas e muito menos ficar refém dos cavaleiros andantes, mas instituir um corpo de indivíduos que possa exercer regularmente funções rotineiras de interesse do universal no seio da sociedade civil, pela ação do poder público. Dessa forma, “o serviço do Estado exige o sacrifício das satisfações individuais, e arbitrárias, das finalidades subjectivas, mas reconhece o direito de, no cumprimento do dever, e só nele, obter suas satisfações” (idem, p. 276). Claro que, qualquer argumento que se tenha em prol da burocracia não pode ignorar seu grande intento de manter estável o funcionamento orgânico das instituições do Estado, e para que isso ocorra a contento, é necessário o mínimo de padronização dos serviços, pagamento em espécie aos funcionários, e uma relação hierárquica das funções, em que exista comando e obediência no propósito de se chegar à "vida social, que é concreta, governada de um modo concreto".

Assim, na importância da hierarquia dentro do conjunto das considerações de Hegel, tem-se, objetivamente, que o seu papel visa coibir abusos e injustiças por aqueles que, detendo qualquer função pública, arroguem-se no direito de extrapolar de sua determinada obrigação, pois estabelece um sistema de relação hierárquica, em que funcionalismo desempenhe suas atribuições baseado na competência e na responsabilidade direta de seus cargos, submetidos à lei, ao princípio do Direito: o plano da normatividade: “A preservação do Estado e dos governados contra o abuso do poder cometido pelas autoridades e pelos funcionários, imediatamente consiste, por um lado, na hierarquia e na responsabilidade e reside, por outro lado, no reconhecimento das comunas e corporações impeditivo de que o arbítrio individual se confunda com o exercício do poder entregue aos funcionários, assim completando, vindo de baixo, a vigilância que, vinda de cima, é insuficiente quanto aos actos particulares de administração" (idem, p. 277).

Nessa passagem, Hegel aponta a importância da burocracia e de sua relação com o Estado moderno, sobretudo aquele surgido após os escombros da Revolução Francesa de 1789. A burocracia, pensada como metáfora, é a porta de entrada do Estado moderno. Nela o que se almeja 
é a imparcialidade da administração pública. Tanto o Estado como os seus governados beneficiamse com a estruturação da burocracia, visto que o processo administrativo torna as relações impessoais e nele o sentido de eqüidade transforma a Europa do século XIX de monarquias absolutas em constitucionais. Dessa forma, na avaliação de Hegel, a hierarquia funcionaria como um sistema de atribuições lógicas guardando o fim de estabelecer o equilíbrio necessário nas relações do público com o privado, não permitindo privilégios, corrupção, peculato e toda sorte de problemas que definhariam o propósito de universalidade do Estado. A hierarquia, nesse particular hegeliano, é uma condição lógica cuja atribuição é criar condições para que os serviços públicos não sofram os impasses tão comuns ao anarquismo da sociedade civil.

Dentro de suas contradições, Hegel ergue um conjunto de relações necessárias entre a existência real do Estado moderno e a eficiência da burocracia. Essa relação é tão íntima no seu pensamento, que julga ter solucionado o problema da representação do verdadeiro Estado a partir do ponto de vista lógico, visto que basta ter-se um grande quadro tecnicamente bem-preparado do ponto de vista moral-intelectual, constituído mediante seleção por mérito, extraído da classe universal (classe média), para ter-se efetivamente solucionado os problemas no seio da sociedade civil (idem, p. 274-278).

É sintomático que, mesmo enquanto defende o ingresso do indivíduo no serviço público mediante prova e exame de aptidão, em consonância com a Revolução de 1789, Hegel busque em Aristóteles o fundamento para defender a tese da classe média como classe universal ${ }^{14}$,

\footnotetext{
14 "Existe em todas as cidades três classes de cidadãos: os muitos ricos, os muitos pobres, e em terceiro lugar os que ficam no meio destes extremos. Como é geralmente aceito que aquilo que é moderado e está no meio é melhor, é sem dúvida melhor desfrutar moderadamente de todos os bens proporcionados pela sorte, pois nessa condição de vida é mais fácil obedecer à razão [...] de fato, os primeiros tendem para a insolência e para a prática de atos de extrema perversidade, e os últimos se tornam maus e inclinados à prática de perversidades mesquinhas, impelidos para tais ofensas pela insolência ou pela maldade. Outrossim, a classe média é a menos propensa a fugir ao exercício de funções públicas” (ARISTÓTELES, 1997, p. 143-144).
}

capaz de em si conter o caráter virtuoso da mediania ${ }^{15}$ e, além disso, de ser o esteio de toda ordem social possível. Talvez, suponho, Hegel queira com isso atentar para o fato de que nem na aristocracia, nem muito menos nas classes populares encontrar-se-ia o material humano para se formar os verdadeiros paladinos da moralidade pública e, por isso, defenda ele, claramente, o elemento burguês como representação de cidadão, de fato em sintonia com a Revolução de 1789.

\section{HEGEL: O PROBLEMA DA PROPRIEDADE PRIVADA.}

No sistema de entendimento de Hegel, a propriedade privada é uma extensão do conceito de propriedade. Não se pode perder de vista que o sistema hegeliano parte de uma identificação do real na perspectiva do ideal, mais precisamente, o real existe no ideal como determinação do autodesenvolvimento do conceito; por isso, a realidade nunca é uma coisa em si mesma, mas sempre uma exteriorização da idéia no plano histórico. Na relação ideal-real é sempre o real determinado pelo ideal. Nesse sentido, Hegel adverte que: "Deve a pessoa dar-se um domínio exterior para a sua liberdade a fim de existir como Idéia. Porque nesta primeira determinação, ainda completamente abstracta, a pessoa é a vontade infinita em si e para si, tal coisa distinta dela, que pode constituir o domínio da sua liberdade, determina-se como o que é imediatamente diferente e separável” (idem, p. 59-60).

Sem precisar o que é propriedade, Hegel pelo menos a situa de forma a ser o fundamento da liberdade, o momento em que a pessoa existe como vontade livre, algo de exterior à pessoa que efetivamente a torna em si mesma indivíduo de relação com o mundo externo. A propriedade não determina a pessoa, mas sua relação com outras e, nesse sentido, a propriedade efetiva um estado de espírito, uma condição necessária para que o indivíduo seja aquilo que deseja ser: livre $e$ determinante de si mesmo.

A propriedade não significa uma naturalidade no sentido de ordem necessária, sua relação está

\footnotetext{
15 "Está, pois, suficientemente esclarecido que a virtude moral é um meio-termo [...] é um meio-termo entre dois vícios, um dos quais envolve excesso e o outro deficiência, e isso porque a sua natureza é visar à mediania nas paixões e nos atos” (ARISTÓTELES, 1973, p. 277).
} 
suficientemente vinculada ao Estado ${ }^{16}$, que a institui como um direito da personalidade, como um direito que distingue a situação do indivíduo no mundo. Hegel está convencido de que a propriedade torna o homem independente dos arbítrios de outrem, por isso a defende no sentido burguês de expressão de si mesmo enquanto disposição capaz de autogerência dos seus interesses. Se considerarmos que a propriedade como tal sempre definiu as relações que as pessoas estabeleceram entre si, que no seu fundamento separou os que têm daqueles que não têm, colocando estes em posição inferior em relação àqueles, Hegel não tem outra alternativa senão pensar que o melhor para o indivíduo ser no mundo moderno está na posse da propriedade, pois o ideal burguês, ao privilegiar a individualidade, toma-a como propriedade dos indivíduos livres.

Para Hegel, o homem tem o direito de se manifestar por meio das coisas, por meio daquilo que produz, daquilo que o identifica na sociedade civil burguesa. Por esse motivo, não pode ser impedido de se apropriar das coisas e muito menos de si mesmo. Hegel defende o direito de o homem ter como propriedade fundamental as suas qualidades subjetivas: as intelectuais e as morais, advindas do processo cultural, e, sendo assim, torna-as posse jurídica, uma propriedade íntima do espírito, o que identifica e distingue os homens no processo de suas relações sociais. Por isso, a defesa da propriedade em si é a defesa do homem manifestar-se enquanto ser que dispõe da possibilidade de possuir direitos na adequação do dever de respeitar aquilo que não lhe pertence e de alguma forma impor esse mesmo princípio aos outros face sua liberdade ${ }^{17}$. A liberdade só se realiza por meio da vontade humana que, ao seu turno, origina-se no espírito, e por esse motivo a liberdade assemelha-se ao exercício da vontade; logo, vontade e liberdade são sinônimos que para Hegel efetivam-se quando ao homem é possível sua realização na propriedade, no momento em que a liberdade é a própria subjectividade.

16 "E onde não foi estabelecido um poder coercitivo, isto é, onde não há Estado não há propriedade, pois todos os homens têm direito a todas as coisas” (HOBBES, 1997, p. 123).

17 “Onde não há Estado nada pode ser injusto. De modo que a natureza da justiça consiste no cumprimento dos pactos válidos, mas a validade dos pactos só começa com a instituição de um poder civil” (HOBBES, 1997, p. 124).
Propriedade, segundo Hegel, é antes de tudo um princípio que norteia a liberdade como fundamento do indivíduo. Não é um fim para garantir a posse como construção jurídica ou solução política para debelar carências. Propriedade no sentido de debelar carências constitui-se como um meio para a solução desses mesmos problemas, mas em si mesma a propriedade é o princípio sobre o qual a liberdade funda-se. Nesse sentido, Denis Rosenfield assinala que "a propriedade é uma categoria que dá a Hegel a possibilidade de pensar, numa etapa primeira do movimento de concreção da pessoa na exterioridade das coisas, o processo graças ao qual a vontade abandona os labirintos de sua subjetividade para aventurar-se nos domínios da imediação do ser. A pessoa determina a sua imediaticidade e a sua individualidade procurando apropriar-se de um mundo que lhe resiste" (ROSENFIELD, 1983, p. 69).

Como bem se presta essa ilustrativa passagem de Rosenfield, a propriedade no pensamento de Hegel é peculiar e está mais como uma determinação filosófica - portanto, lógica - do que como uma determinação eminentemente política, de ordem prática, como em John Locke. Segundo o pensador inglês, a propriedade, embora seja um conjunto de bens, vida e liberdade, uma determinação da natureza, não assume, como em Hegel, uma determinação do indivíduo dentro da sociedade, a partir de como ela é. Para Locke, a propriedade constitui a base de um sistema associativo entre os homens, isto é, os homens deveriam organizar-se no melhor governo possível, cujo escopo seria a guarda, o uso e a disponibilidade da propriedade sem nenhuma ingerência externa. No pensamento de Locke, sendo a propriedade um direito natural, existe muito antes da própria organização política ${ }^{18}$. Deus criou o mundo para o homem e o fez detentor de toda riqueza existente para benefício daqueles que pudessem usá-la com razão e sobriedade, que, explorada pelo trabalho, daria aos homens o sustento e a própria liberdade, visto que o trabalho, o corpo e o produto dessa relação formariam a propriedade de si mesmo.

18 “E não é sem razão que procura de boa vontade juntarse em sociedade com outros que não estão já unidos, ou pretendem unir-se, para a mútua conservação da vida, da liberdade e dos bens a que chamo de propriedade” (LOCKE, 1973, p. 88). 
Inversamente, para o filósofo alemão, a propriedade não constitui um princípio da natureza, pois esta não é livre (HEGEL, 1990, p. 65). A propriedade é uma das tantas mediações encontradas por Hegel para a expressão da pessoa que é na verdade sujeito, que em si mesmo é abstração, e por isso a propriedade assume na sua filosofia política um papel de efetivar o indivíduo na sociedade civil burguesa, a dignificá-lo por meio da manifestação de algo que o apresente de forma concreta. Assim, a propriedade em Hegel, não sendo base de nenhum sistema político, dá-se como esteio para que o homem manifeste-se politicamente no seio da sociedade como algo de si e não como algo em si alheio à sua vontade. Para Hegel, os homens não se organizam em sociedade para usufruir a propriedade sob garantias públicas, mas sim na dimensão pôr a termo a liberdade. Em síntese, a propriedade em Locke é uma manifestação da natureza sob a qual os homens por bem deveriam viver, ao passo que em Hegel é uma determinação do espírito para que os homens vivam em liberdade (idem, p. 67).

Entretanto, para que a propriedade torne-se privada, isto é, torne-se de uma pessoa, é necessário que, além da vontade de se apossar da coisa (animus), haja, por parte desse interessado, a possessão da coisa, e que, em contrapartida, não haja nenhum impedimento interposto por outrem, ou seja, que outrem não manifeste também o interesse de possuir a mesma coisa. Nessa relação de princípios, parece que Hegel toma de Locke semelhante argumento: “Ninguém pode fechar qualquer parte do terreno ou dele apropriarse sem o consentimento de todos os membros da comunidade" (LOCKE, 1973, p. 54).

\section{O PROBLEMA DA REPRESENTAÇÃO POLÍTICAEADEMOCRACIA}

Não se pode esquecer que a associação entre liberalismo e democracia foi um processo em parte atribuído às lutas que os próprios liberais travaram contra os socialistas no século XIX (BOBBIO, 2000, p. 323), isso porque entre liberalismo e democracia nunca houve uma relação natural como hoje se deseja passar. Embora para os liberais a democracia sempre tenha sido vista como uma forma governativa fundamentada na liberdade, seus receios estavam intimamente ligados ao fato de que o preceito de liberdade estaria intimamente ligado a um outro, tão ou mais importante: a igualdade. Por isso que os liberais do século XIX ficavam receosos (como ficam até hoje) com o significado real da democracia: igualdade para a manifestação da liberdade, isso porque a liberdade não pode ser um pressuposto da igualdade. No sentido da lógica associativa, a igualdade é o substantivo para que eu e o outro possamos externar sentimentos e opiniões no mínimo respeitadas ${ }^{19}$.

Muitos liberais do século XIX não defenderam a democracia como necessidade vital para uma associação politicamente justa. Preocupavam-se sobremaneira com a liberdade: para negociar, possuir propriedade e poder contratar como ato de inteira disposição de si mesmo. Para um liberal clássico do século XIX, a igualdade era um postulado estranho ao liberalismo, que deveria ser combatido, pois contrariava essencialmente os interesses da representação parlamentar da época, que se fundava no voto restrito àqueles que possuíam propriedade.

Por ser um grande leitor dos clássicos, atento aos escritos políticos de sua época e arguto observador dos homens em sociedade, Hegel não poderia ignorar a democracia como um elemento que, após a Revolução Francesa, tomou uma dimensão de ordem fundamental nos debates políticos de então. Aliás, Hegel sempre viu com reservas a democracia pensada única e exclusivamente como sistema de votos. Compreendia que uma democracia assim não daria conta das necessidades políticas de uma Alemanha dividida. Segundo Herbert Marcuse (1898-1979), em sua obra Razão e revolução, Hegel escreveu sua Filosofia do Direito em defesa do Estado, isso porque considerava que muitos movimentos pseudodemocráticos alemães ${ }^{20}$ representavam ameaça maior à liberdade do que as próprias

19 “Um princípio fundamental da forma democrática de governo é a liberdade - a liberdade, segundo a opinião dominante, somente pode ser desfrutada nesta forma de governo, pois diz-se que ela é o objetivo de toda a democracia. Mas um princípio de liberdade é governar e ser governado alternadamente, pois o conceito popular de justiça é a observância da igualdade baseada no princípio da maioria, e não no do mérito, e se este é o conceito de justiça dominante, a maioria deve ser necessariamente soberana, $\mathrm{e}$ a decisão da maioria deve ser final e constituir a justiça, pois costuma-se dizer que cada cidadão deve ter uma participação igual” (ARISTÓTELES, 1997, p. 204).

20 Burschenschaften (agremiações estudantis) e os Turnvereine (clubes de ginástica) Em nome da liberdade e 
autoridades constituídas (MARCUSE, 1978, p. 171), que, a exemplo do Terror instituído pelo Comitê de Salvação Pública na França revolucionária, invertia o universal pelo particular (ALVES, 1983, p. 156). Hegel não vislumbrou na democracia o que a monarquia proporcionava-lhe: o princípio da unidade pela autoridade do monarca no projeto de efetivação do universal contra o particular, isso como razão histórica. Nesse caso, pondera: "Diz-se que todos os indivíduos isolados deverão participar nas deliberações e decisões sobre os assuntos gerais do Estado porque são membros do Estado, os assuntos do Estado a todos dizem respeito, todos têm o direito de se ocupar do que é o seu saber e o seu querer. Tal concepção, que pretende introduzir no organismo do Estado o elemento democrático sem qualquer forma racional - obliterando que o Estado só é Estado por uma forma racional -, afigura-se muito natural porque parte de uma determinada abstração: serem todos membros de um Estado, e porque o pensamento superficial não sai das abstrações [...]. O membro do Estado é membro de tal ou tal ordem, e só com esta determinação objetiva poderá ele ser considerado dentro do Estado" (HEGEL, 1990, p. 288-289).

Com isso, Hegel afirma claramente que a introdução do "elemento democrático sem qualquer forma racional”, no interior do Estado, não o transforma em algo melhor, e possivelmente tornálo-ia pior, isso porque o Estado só é Estado em razão de sua racionalidade, e de alguma maneira os defensores do "elemento democrático" esquecem-se ou ignoram esse detalhe. Hegel considera a democracia uma abstração que não tem realidade histórica, não tem relação de concretude para gerar instituições voltadas à satisfação dos interesses da universalidade anunciada pela idéia desenvolvida pelo Estado. Essa idéia posta em processo pelo Estado é o ingresso

da igualdade entre os homens, o povo estadunidense constituiu-se livremente em uma república com representação pelo voto. Em nome de tais princípios, o povo francês derrubou a monarquia e instituiu uma república que pudesse racionalmente levar adiante os mais simples direitos dos homens. Paradoxalmente, em nome dos mesmos princípios, a pequena burguesia alemã, após a libertação dos estados alemães do jugo francês, através de argumentos liberais e democráticos, propunha ódio aos judeus, católicos, franceses, e fundava o progresso alemão num salvador do espírito germânico etc. do homem para si, dentro de suas fileiras, entretanto para isso, Hegel julga que os membros do Estado são positivamente seus membros quando participam dele por meio de uma ordem (determinação objetiva) ${ }^{21}$, membros enquanto espécie e não enquanto gênero, pois em sua corporação atingem o universal. O que Hegel julga verdadeiramente é que a monarquia em si é uma determinação histórica germânica e, por fim, o elemento decisivo na unificação políticoeconômica da Alemanha, o que ocorrerá em 1871 por essas mesmas forças.

Em uma passagem da Filosofia do Direito, Hegel aponta claramente que a opinião de muitos não significa necessariamente a detenção do universal, mas, sim, em muitos casos, apenas o sentido de particularidade, o sentido de uma opinião sobre assuntos que pedem inteiro conhecimento e profundidade. Não são os indivíduos isolados com opiniões isoladas que dinamizam a sociedade civil, mas objetivamente a representação por meio dos mecanismos das ordens, das corporações, das classes, da delegação política. Segundo Rosenfield, não se trata de acusar Hegel de ser contra a democracia. Em seu entendimento, o que Hegel nega-se a aceitar é ainda a forma não-racional que apresenta a democracia, isto é, generalidades abstratas ${ }^{22}$. Mais que isso, é a sua origem que repousa nas abstrações particulares, nos interesses puramente pessoais, ignorando que em uma organicidade estatal o que se determina é o universal, não como soma de partes, mas como estas no seio do todo, visto este logicamente preceder às partes.

Segundo Hegel, a representação parlamentar dá-se por competência dos interesses da particularidade dentro da universalidade, ou melhor, não se trata de uma representação a partir

21 “A participação orgânica dos indivíduos na vida política tornou-se uma determinação da Idéia do Estado como vontade substancial. A participação atomística dos indivíduos, pelo contrário, é a determinação de uma filosofia que reduz o Estado a um contrato social” (ROSENFIELD, 1983, p. 250).

22 “O problema não é então afirmar que Hegel é contra a democracia, mas, pelo contrário, trata-se de assinalar que ele é adversário de sua forma ainda não racional [...]. A participação de todos nos assuntos públicos só tem lugar através de uma mediação que garanta efetivamente a expressão política das relações da sociedade civil-burguesa” (idem, 1983, p. 256). 
de sujeitos isolados, especificamente relacionados a interesses abstratos, mas pelo fato de se firmar como representação de interesses da sociedade no seu conjunto. A representação em Hegel espelha-se, sobretudo, no interesse que se move em torno das necessidades da sociedade, por isso entende que a delegação política só pode ser pela inteligência e conhecimento do que constitui a particularidade. Por isso, é perigoso afirmar que Hegel é antidemocrático ou autoritário. Em sua época, a democracia estava longe de ser como a conhecemos. Sob os pontos de vista formal e material, a democracia que hoje conhecemos deu os seus primeiros passos no mundo moderno pela experiência concreta dos Estados Unidos da América do Norte, que, por sua vez, no primeiro momento, ainda via-se em debates tremendos para saber que tipo de democracia queria-se, até descobrir, ao fim, o melhor caminho para sua institucionalização, apesar das tortuosas contingências (cf. HAMILTON, JAY \& MADISON, 1993). Vide o próprio Thomas Jefferson (1743-1826), um dos expoentes do pensamento democrático contemporâneo, ao mesmo tempo em que declara a igualdade natural dos homens, vê-se às turras com a escravidão de negros africanos nos Estados Unidos. É muito simples tomar as idéias dos seus titulares longe do tempo em que estão envolvidas.

Um dos corolários da democracia representativa, o sufrágio universal institui, por conseguinte, a representação política partidária que, aos olhos de Hegel, é visto como verdadeiro celeiro de interesses ligados à contingência e à particularidade (HEGEL, 1990, p. 293). A política partidária para Hegel é uma das formas de participação nos negócios públicos, por sinal acidental e incongruente, por não assegurar que todos realmente assentem-se nos lugares visando determinações públicas. Como a democracia é um sistema que pressupõe disputa, e disputa leva ao plano dos interesses particulares - um perde enquanto outro ganha -, Hegel entende que tal forma de administração da coisa política em nada garantiria a concretização da liberdade como valor universal e muito menos levaria a Alemanha a lugar algum (ROSENFIELD, 1983, p. 257).

Para entender o pensamento político de Hegel, é preciso situá-lo dentro do espírito do seu tempo, é necessário perceber que esse filósofo é antes de tudo um metafísico. Por isso não se preocupa em partir de um real específico como ponto determinado, mas sim de um real que seja compreendido pela idealidade de si mesmo. O legislativo na concepção hegeliana difere do construído pela contemporaneidade, isto é, um foro de discussões por vezes intermináveis. Para Hegel, a casa legislativa apenas detém-se naquilo que for de competência da sociedade civil, e não ultrapassa esses limites, cabendo ao poder soberano a tarefa de sustentar e promover o universal por meio do poder governativo, pelo seu pessoal devidamente qualificado no interesse do Estado. Nessa relação entre os poderes Governativo e Legislativo, Hegel privilegia o primeiro por entender que sua natureza é universal e não particular: “A opinião que a consciência vulgar habitualmente perfilha sobre a necessidade ou a utilidade da colaboração das ordens na elaboração das leis, consiste, antes de tudo, em crer que os deputados do povo são os que melhor compreendem o que é o bem do povo e os que melhor vontade indubitavelmente possuem sobre o que ao povo convém [...]. Quanto ao primeiro ponto, o que, pelo contrário, é bem verdade é que o povo, na medida em que esta palavra designa uma facção particular dos membros do Estado, representa a parte que não sabe o que quer. Saber o que se quer e, ainda mais, saber o que a vontade em si e para si, a razão, quer, só pode ser o fruto de um profundo conhecimento e de uma intuição que, precisamente, o povo não possui. A contribuição que ao bem geral e à liberdade pública as assembléias de ordem vêm dar, não reside, se nisso reflectirmos um pouco, na sua intuição particular. Com efeito, os altos funcionários do Estado têm necessariamente um entendimento mais profundo e vasto da natureza das disposições e exigências do Estado [...] não precisam de tais assembléias para fazer o melhor e são eles que, nas assembléias de ordens, fazem o melhor" (HEGEL, 1990, p. 282).

Abusando da extensa citação, deseja-se com ela exemplificar o que Hegel pensava do Legislativo: um momento do conceito do Estado totalmente subordinado ao poder soberano por meio da ação do Governativo. Para Hegel, o Legislativo configura-se em um poder auxiliar nas decisões de natureza pública; dele chegam informações sobre as particularidades da sociedade civil, que por sua vez são elevadas à categoria de universal e por fim efetivadas como prestação de serviços que o governo entende essenciais ao povo. 
Aventuro-me a dizer que o poder Legislativo assume, para Hegel, apenas uma função consultiva, como um órgão consultor do poder soberano. Quando não, do Legislativo partiriam algumas iniciativas que deveriam ser submetidas ao monarca na qualidade de verificar o sentido universal do Estado. A representação para Hegel tinha um sentido de bem público e liberdade racional, constituía-se numa instituição, só que não tão importante quanto a soberania do monarca, o regime judiciário etc. O que na verdade vale dizer é que a representação parlamentar, segundo Hegel, possui importância secundária, pois não é o número que define a melhor ação do Estado, mas sim por quem é realizada essa mesma ação do Estado.

\section{CONCLUSÕES}

Segundo Hegel, os fenômenos históricos são essencialmente políticos porque o desdobramento da história tem por instância última a efetivação do Estado. Como o Estado é o centro da vida éticopolítica, a história marcharia sem sombra de dúvida para essa realização. Hegel, que tinha no Estado a pretensão da vida ética, o momento da história em que o espírito, voltando-se para si mesmo, compreenderia a totalização da existência, pensa a política no sentido grego do homem participando dos negócios da cidade, ativamente inserido numa ordem cuja preocupação não poderia ser outra senão a plena efetivação de si no conjunto de interesses da coletividade. Destarte, Hegel pensa e monta sua idealização política tendo por excelência a liberdade que só pode ser real no interior do Estado como comunidade ética, como princípio de uma relação em que transformaria a sociedade na integração dos indivíduos ligados pela cultura e pela expectativa comum de uma vida livre. Nesse sentido, a vida ética permite compreender o Direito como dever e o dever como Direito, ou seja, a responsabilidade de todos é um interesse universal e importante na medida em que constituem laços integrativos. Esse Estado não seria a soma dos eus particulares, mas um grande $\mathrm{Eu}$ em que todos estariam inseridos como força do autodesenvolvimento da consciência de si como princípio coletivo.

Hegel tem no Estado a totalidade que absorveria, num só plano, o "chefe de família” e o cidadão, incluindo-os em uma ordem necessária e logicamente pronta para romper com a atomização do individualismo burguês construído a partir do século XVII. Dessa forma, Hegel pensa romper com o individualismo ao fundir a sociedade civil e o Estado político no mundo moderno. No entanto, conforme Marx, em sua Critica da Filosofia do Direito de Hegel, que data de 1843, a iniciativa de Hegel ficou comprometida na medida em que utilizou os elementos que procurava combater: a política, o individualismo burguês, a propriedade privada, o Direito privado, a moral privada e a ausência do povo nos negócios do Estado; na verdade, um conjunto de contradições desafiando a própria lógica montada para responder os desafios do problema político (cf. MARX, 1946).

Assim, Hegel é acusado de criar um quebracabeça lógico de elementos feudais com burgueses, procurando aprisionar o real e dele apresentar novas representações de cunho estritamente metafísicas. Como fim do seu pensamento filosófico - e, por extensão, da totalidade que representa -, Hegel elege a síntese como a apoteose final do pensamento que se pensa a si mesmo. Mas disso cria armadilhas para si, ignorando que a realidade lógica de seu sistema é uma coisa completamente diferente do que ocorre na lógica da realidade. Embora os elementos feudais existam, na Alemanha, ao lado dos burgueses, isso não confere a Hegel, sob o ponto de vista dialético, razão em afirmar a imutabilidade de tal momento histórico. Por outro lado, para Marx, o que existe de real é a sociedade movendose nas suas contradições internas, e por elas acomodando-se ou transformando-se conforme as forças, os interesses e as necessidades em jogo, desenvolvidas nas condições objetivas, definidas pelas "condições materiais de existência" (ROSENZWEIG, 2008, p. 543).

Segundo Marx, Hegel promove tantas contradições que acaba usando a propriedade privada, particularmente o morgadio ${ }^{23}$, para garantir o ingresso de uma classe específica da

23 Derivado de majoratus, da baixa latinidade, era o vocábulo empregado na terminologia do Direito antigo para indicar vínculo instituído a certos bens, a fim de que se transmitissem seguidamente aos sucessores, com a mesma imposição, sem se pode vender ou dividir. O morgadio, assim, apresentava-se perpétuo e indivisível, e tinha por objetivo manter os bens vinculados para conservação do nome da família. O herdeiro do morgado era o primogênito, e a este, por extensão, também se dava a denominação de morgado. E designava, ainda, o direito de suceder nos bens vinculados ou que constituíam o morgado. 
sociedade civil no centro do Estado, apontando o poder Legislativo como o eixo da universalidade, mas impedindo, ao mesmo tempo, o acesso de todos, quando barra o número (povo) enquanto elemento democrático. Sustenta o Estado como o reino da reconciliação e, ao menor piscar de olhos, sustenta a burocracia como o espírito do Estado. Enfim, Marx assinala que, ao separar moral e Estado, Hegel apresenta a moral do Estado moderno: a ilusão racional em torno do Direito Privado. É por esse conjunto de fatores que Marx apela para o sentido de inverter as proposições hegelianas, isso por também perceber que, logicamente, as construções hegelianas estão, a princípio, montadas numa inversão a priori, ou melhor, Hegel não olha a materialidade como ela é, por isso é preciso uma metodologia da desinversão do ideal pelo real. A presença do real, para Hegel, converte-se em idealizações, porque só essas são reais e a experiência não é condição de universalidade, o que faz as abstrações constituírem-se num plano concreto.

No entanto, mesmo sendo relevante o conjunto das oposições de Marx a Hegel, ao ler-se $A$ Filosofia do Direito, levando em consideração o critério de apatia, por força da observação, chegase à conclusão de que seu pensamento parece retratar não só o Estado moderno, mas também o contemporâneo, sobretudo nos últimos trinta anos, em que cada vez mais o poder Legislativo perde, por motivos diversos, o seu papel de legislar, em favor do poder Executivo, cabendo a este o incremento do universal no seio das particularidades. Por isso, estando certo ou não, constata-se que ao poder Legislativo ficou reservado o papel de moldura constitucional. O poder Executivo, por outro lado, trouxe para si a tarefa de ser o grande poder no interior das instituições políticas, constituindo-se na própria representação da soberania. Portanto, nada mais hegeliano do que a atualidade dos Estados nacionais.

A Filosofia do Direito busca, por meio de suas especulações, prever que o plano do Estado portanto, o plano do conceito do Direito - é a liberdade como meio-fim por meio da normatividade, enquanto garantias políticojurídicas, tomando o indivíduo como ser social. Conclui-se, assim, que o pensamento político de Hegel, por mais paradoxal que seja, ainda é uma leitura consistente contra os esforços atomizantes do pensamento liberal, que insiste, apesar da tragédia social contemporânea, em ser a melhor construção política para se pensar a realidade e promover o ideal de uma sociedade, no mínimo, inteligente.

Wellington Trotta (wtrotta@ig.com.br) é Mestre em Ciência Política pela Universidade Federal do Rio de Janeiro (UFRJ), doutorando em Filosofia na mesma instituição e Professor da Universidade Estácio de Sá (Unesa).

\section{REFERÊNCIAS BIBLIOGRÁFICAS}

ALVES, J. L. 1983. Rousseau, Hegel e Marx. Percursos da razão política. Lisboa : Livros Horizonte.

ANDERSON, P. 1980. Passagens da antiguidade ao feudalismo. Porto : Afrontamento.

1984. Linhagens do Estado absolutista. Porto : Afrontamento.

ARISTÓTELES. 1973. Ética, a Nicômaco. Coleção. "Os pensadores”. São Paulo : Abril. 1997. Política. Brasília : UNB.

BOBBIO, N. 1995. Estudos sobre Hegel. São Paulo : Brasiliense.
BOBBIO, N.; MATTEUCCI, N. \& PASQUINO, G. (orgs.). 2000. Dicionário de política. V. I. $10^{a}$ ed. Brasília : Universidade de Brasília.

DURANT, W. 1996. A história da filosofia. Coleção. “Os pensadores”. São Paulo : Nova Cultural.

FREITAG, B. 1992. Itinerários de Antígona : a questão da moralidade. São Paulo : Papirus.

GIORDANI, M. C. 1985. História dos reinos bárbaros. Petrópolis : Vozes.

HAMILTON, A.; JAY, J. \& MADISON, J. 1993. Os artigos federalistas, 1787-1788. Rio de Janeiro : Nova Fronteira. 
HARTMANN, N. 1983. A filosofia do idealismo alemão. Lisboa : C. Gulbenkian.

HEIDEGGER, M. 1973. Hegel e os gregos. Coleção. “Os pensadores”. São Paulo : Abril.

HEGEL, G. W. F. 1968. Ciencia de la lógica. Buenos Aires : Solar.

1974. Introdução à História da Filosofia. Coimbra : A. Amado.

1990. Princípios da Filosofia do Direito. Lisboa : Guimarães.

1991. Introdução à história da filosofia. Lisboa : editora 70.

1995a. Enciclopédia das Ciências Filosóficas. V. I. São Paulo : Loyola.

1995b. Enciclopédia das Ciências Filosóficas. V. III. São Paulo : Loyola.

1999a. Fenomenologia do espírito. V. I. Petrópolis : Vozes.

1999b. Filosofia da História. Brasília : UNB.

2001. Cursos de estética. V. I. São Paulo : Universidade de São Paulo.

HESSEN, J. 1987. Teoria do conhecimento. Coimbra : A. Amado.

HOBBES, T. 1997. O leviatã. Coleção. “Os pensadores”. São Paulo : Nova Cultural.

INWOOD, M. 1997. Dicionário Hegel. Rio de Janeiro : J. Zahar.
KONDER, L. 1991. Hegel : a razão quase enlouquecida. Rio de Janeiro : Campus.

LEÃO, C. 1977. Aprendendo a pensar. Petrópolis : Vozes.

LOCKE, J. 1973. Segundo tratado do governo civil. Coleção. “Os pensadores”. São Paulo : Abril.

LUKÁCS, G. 2007. O jovem Marx e outros escritos de filosofia. Rio de Janeiro : UFRJ.

MARCUSE, H. 1978. Razão e revolução. Rio de Janeiro : Paz e Terra.

MARX, K. 1946. Critica de la filosofía del Estado de Hegel. Buenos Aires : Claridade.

PINHEIRO, R. L. 1983. História resumida do Direito. Rio de Janeiro : Rio.

RAMOS, C. A. 1993. A crítica marxista do Estado hegeliano. Revista de Sociologia e Política, Curitiba, n. 1, p. 57-64.

ROSENFIELD, D. 1983. Política e liberdade em Hegel. São Paulo : Brasiliense.

ROSENZWEIG, F. 2008 Hegel e o Estado. São Paulo : Perspectiva.

SAMPAIO, L. S. C. 2000. Lógica ressuscitada. Rio de Janeiro : UERJ.

VERNANT, J.-P. 1992. As origens do pensamento grego. Rio de Janeiro : B. Brasil.

WEBER, T. 1993. Hegel : liberdade, Estado e história. Petrópolis : Vozes. 


\section{LA PENSÉE POLITIQUE DE HEGEL À LA LUMIÈRE DE SA PHILOSOPHIE DU DROIT}

\section{Wellington Trotta}

L'article analyse la pensée politique de Hegel à partir de sa « Philosophie du Droit », en faisant une présentantion systématique de ce que l'auteur a compris comme philosophie dont la politique était comme une conséquence inévitable, puisque son système théorique privilégiait l'unité logique. J’ai fait appel, dans l'élaboration de l'article, à un critère fort simples : présenter la pensée politique hégélienne à la lumière de son propre temps, prenant en compte les difficultés habituelles que tous ressentent pour exprimer des idées universelles à partir d'expériences particulières. Ainsi, je souhaite souligner que, bien que Hegel ait compris l'État dans la perspective de l'universel concret, son regard est prussien et tourné vers les problèmes de l'unité allemande. L'article est divisé en deux parties : la première est un exposé du contenu philosophique de l'auteur, tandis que la deuxième partie cherche à étudier systématiquement sa pensée politique, ayant comme borne sa « Philosophie du Droit ». Cette systématisation est envisageable puisque à l'origine le présent article intégrait mon mémoire de master, dans lequel j'ai pu établir une relation entre Hegel et la pensée de Marx de 1843, présentée dans la « Critique de la Philosophie du Droit de Hegel ». À la fin, en guise de conclusion, j'argumente que, même si l'ensemble des critiques de Marx sont importantes, la pensée hégélienne semble retracer non seulement l'État moderne, mais aussi l'État contemporain, surtout ceux des trente dernières années, où de plus en plus le pouvoir législatif perd, pour des raisons multiples, son rôle de législateur, et est remplacé par le pouvoir exécutif à qui revient l’approfondissement de l'universel au sein des particularités.

MOTS-CLÉS : Hegel ; Philosophie du Droit ; Marx ; État moderne ; philosophie allemande.

\section{MOBILITÉ AU TRAVAIL ET CONTRÔLE SOCIAL : TRAVAIL ET ORGANISATIONS À} L’ÈRE NÉO-LIBÉRALE

\section{Fábio Guedes Gomes}

Le travail réalise une relecture des chapitres historiques de Le capital de Karl Marx, dans la perspective de travailler sur le concept de « mobilité du travail », tel qu’il est développé dans le livre qui sert d'appui théorique à cet article : “Movilidad del trabajo y acumulación de capital”, du français Jean-Paul de Gaudemar. Cet ouvrage est peu connu au Brésil, surtout en économie politique. Pourtant, il est important pour la capacité d'approfondir la notion de ce concept et pour participer à la construction d'une interprétation plus poussée des déterminations du capitalisme contemporain et de ses nouvelles formes d'exploitation, comme la mobilité, la soutraitance, la reengineering, etc. Ainsi, l'article cherche, à partir de la compréhension du concept de mobilité du travail, à mener quelques incursions dans les thèmes essentiels du processus d'accumulation capitaliste, surtout dans des domaines comme celui du chômage et des procédés de travail qui mènent à l'accrue de l'extraction de plus-value relative et absolue qui déclenchent donc la réduction des niveaux moyens de revenu de la majorité de la population des travailleurs, l'accroissement de l'informalité et de la précarité des conditions de vie matérielle. On remarque que l'épuisement du modèle d'accumulation capitaliste, pendant la transition entre les années 1960-1970, a favorisé des changements profonds dans le mode de fonctionnement du système, produisant des formes plus indirectes d'exploitation et des contrôles culturels et idéologiques beaucoup plus sophistiqués et efficaces.

MOTS-CLÉS : mobilité du travail ; contrôle social ; capitalisme ; modernité ; forrmes d'exploitation. 


\section{HEGEL'S POLITICAL THOUGHT THROUGH THE PRISM OF HIS PHILOSOPHY OF LAW} Wellington Trotta

This article analyzes Hegel's political thought, through the prism of his Philosophy of Law. I present a systematic exposition of Hegel's concept of philosophy, which made politics a necessary consequence, given the fact that his theoretical system sought to establish a unitary logic. In elaborating the present text, I have employed a very simple criteria: to present Hegelian political thought through the prism of its own historical moment, taking the common difficulties that all of us experience in expressing universal ideas through singular experiences.. Thus, I would like to note that although Hegel thought of the State from the perspective of the universal concrete, his Prussian gaze is guided by his concern for German unity. The article is divided into two sections. The first provides an exposition of the thinker's philosophical content, whereas the second seeks to carry out a systematic study of his political thought, based on his "Philosophy of Law". This systematization is understandable since the present text was initially a part of my Master's Thesis in which I related Hegel and Marx's thought in the 1843 period, as expressed in the latter's "Critique of Hegel's Philosophy of Law". Lastly, in conclusion, I argue that notwithstanding the relevance of Marx's set of criticisms, Hegelian thought seems not only to provide a portrait of the modern State but also the contemporary one, particularly that of the last 30 years, a period in which legislative power has lost its legislative role, increasingly substituted by the executive which in turn has been confronted by the task of increasing the universality within its particularities.

KEYWORDS: Hegel; Philosophy of Law; Marx; the Modern State; German philosophy.

LABOR MOBILITY AND SOCIAL CONTROL: WORK AND ORGANIZATIONS IN NEOLIBERAL TIMES

\section{Fábio Guedes Gomes}

This paper engages in a re-reading of the historical chapters of Karl Marx's Capital, in the interests of working with the concept of "labor mobility" as it has been developed in the book that serves as the underlying theoretical reference for this article: the French scholar Jean-Paul de Gaudemar's "Labor mobility and capital accumulation". The latter work is little known in Brazil, particularly within the area of Political Economy. Nonetheless, it is extremely important, given its approach to the concept and contribution toward building a more accurate interpretation of the determinants of contemporary capitalism and its new forms of exploitation (flexibilizing, sub-contracting, reengineering, etc.) Thus, through a heightened understanding of the concept of labor mobility, we seek to make some incursions into central themes on the process of capital accumulation, with particular concern for issues such as unemployment and labor processes that lead to increased extraction of relative and absolute surplus value and that consequently lead to a drop in the wage levels of a large part of the working classes, increasing the informality and precariousness in their material conditions of life. We are able to observe that the exhaustion of patterns of capital accumulation during the transition from the 1960s to the 1970s has promoted profound changes in the way the system functions, leading to more indirect forms of exploitation and to more sophisticated and efficient forms of cultural and ideological control.

KEYWORDS: labor mobility; social control; capitalism; modernity; forms of exploitation. 